Article

\title{
Evaluation of the Aqua-MODIS C6 and C6.1 Aerosol Optical Depth Products in the Yellow River Basin, China
}

\author{
Miao Zhang ${ }^{1, *}$, Jing Liu ${ }^{2}$, Wei Li ${ }^{1}$, Muhammad Bilal ${ }^{3, *}$, Feifei Zhao ${ }^{1}$, Chun Zhang ${ }^{1}$, \\ Bo Yuan ${ }^{4}$ and Khaled Mohamed Khedher ${ }^{5,6}$ (D) \\ 1 School of Environmental Science and Tourism, Nanyang Normal University, Wolong Road No.1638, \\ Nanyang 473061, China \\ 2 Lingnan College, Sun Yat-sen University, Guangzhou 510275, China \\ 3 School of Marine Sciences, Nanjing University of Information Science \& Technology, Nanjing 2100444, China \\ 4 College of Computer and Information Engineering, Nanyang Institute of Technology, \\ Nanyang 473004, China \\ 5 Department of Civil Engineering, College of Engineering, King Khalid University, Abha 61421, Saudi Arabia \\ 6 Department of Civil Engineering, Institut Superieur des Etudes Technologiques, Campus Universitaire \\ Mrezgua, Nabeul 8000, Tunisia \\ * Correspondence: zm_liesmars@whu.edu.cn (M.Z.); muhammad.bilal@connect.polyu.hk (M.B.); \\ Tel.: +86-151-3909-7793 (M.Z.)
}

Received: 19 May 2019; Accepted: 20 July 2019; Published: 24 July 2019

check for

Abstract: In this study, Aqua-Moderate Resolution Imaging Spectroradiometer (MODIS) Collection (C6) and C6.1 Dark Target aerosol optical depth (AOD) retrievals at $3 \mathrm{~km}$ (DT3K) and $10 \mathrm{~km}$ (DT10K), Deep Blue AOD retrievals at $10 \mathrm{~km}$ (DB10K), and combined DT and DB (DTB) AOD retrievals at $10 \mathrm{~km}$ resolutions were validated from 2002 to 2014 against ground-based sunphotometer AOD measurements obtained from the Chinese aerosol remote sensing network (CARSNET). The CARSNET AOD data were obtained for sites at Mt. Waliguan (MW), Lanzhou (LZ), Ulate (UL), and Zhengzhou (ZZ) located in the Yellow River basin (YERB) region, China. Errors and agreement between satellite and ground data were reported using Pearson's correlation (R) and relative mean bias (RMB). Results showed that the DT3K C6.1 highest quality flag $(\mathrm{QF}=3)$ AOD retrievals were well correlated with the sunphotometer AOD data, with an R of 0.82 and an RMB of 1.01. Overestimation and underestimation in DT AOD retrievals were observed for AOD $>1.1$ and AOD $<1.1$, respectively. A significant underestimation of $37 \%$ in DB10K AOD retrievals was observed across all the sites except ZZ, which was indicated by a low-value RMB (0.63). Spatial distribution maps showed high AOD values $(>0.8)$ over the lower part of the YERB and low AOD values $(<0.4)$ across the upstream part of the YERB. This might be due to a large number of aerosol emissions over the lower developed areas and a scarcity of aerosols over the upstream mountain areas. Overall, this study supports the use of DT10K C6.1 AOD retrievals over the western semi-arid and arid regions of the YERB and DTB10K AOD retrievals over the north-central water system and eastern plain regions of the YERB.

Keywords: CARSNET; MYD04; AOD; Collection 6.1; DT; DB; Yellow River basin

\section{Introduction}

Aerosols are tiny suspended particles in the earth's atmosphere that can significantly affect climate change, air quality, and human health [1-8]. Specifically, particulate matter (PM) with a diameter of less than $2.5 \mu \mathrm{m}\left(\mathrm{PM}_{2.5}\right)$ can stay in the atmosphere for a long time and can also enter human lungs and other organs through breathing, leading to various diseases [9]. Therefore, to meet the needs of 
climate-change assessment and air-quality monitoring, it is necessary and crucial to conduct long-term continuous aerosol observations at a regional scale [10-13].

Scientists have made many efforts in establishing global and national aerosol observation networks for regular measurements of aerosol optical properties, such as the aerosol robotic network (AERONET) and the Chinese aerosol remote sensing network (CARSNET) [14]. These networks provide aerosol optical properties directly by using ground-based sunphotometers [15-17]. However, due to the high cost of construction and operation of ground-based sunphotometers, they are few in number at a global scale, especially in remote areas. Therefore, satellite remote sensing is expected to become an ideal technology for aerosol optical and radiation characteristic observations at regional and global levels. In recent decades, various satellite sensors including the Moderate Resolution Imaging Spectrometer (MODIS) have been used for regular aerosol monitoring [18-20].

Recently, MODIS Collection (C6) aerosol products have been widely validated over land and ocean surfaces [21-33], including the Indian subcontinent [34-36], Southeast Asia [37], East Asia [38,39], Greece [40,41], and China [42-45]. Bilal et al. [46] showed the missing aerosol optical depth (AOD) pixels for the MODIS C6 Dark Target (DT) and Deep Blue (DB) AOD products during several incidental haze events which occurred in 2013 over the Beijing-Tianjin-Hebei region. These missing pixels might be due to the more stringent cloud mask used in the DT and DB inversion algorithms. In addition, MODIS AOD products have also been used to estimate PM concentrations from local to global scales $[9,33,47,48]$. Wang et al. [49] evaluated the performance of VIIRS (Visible Infrared Imaging Radiometer Suite) and MODIS C6 AOD products in the Yangtze River basin (YRB). Bilal et al. verified the performance of MODIS C6 and C6.1 aerosol products on different vegetation surfaces globally [50]. In conclusion, the evaluations of MODIS C 6 and C6.1 aerosol products are currently concentrated in developed regions in eastern and southern China, such as Beijing-Tianjin-Hebei [43,46,48,51,52], Wuhan $[53,54]$, and the YRB $[49,55,56]$. Little research has been conducted for the entire Yellow River basin (YERB) in central-north and north-western China.

The Yellow River basin is one of the underdeveloped areas in China [57]. Due to the lack of surface air quality monitoring stations, especially in the middle and upper reaches of the YERB, satellite remote sensors such as MODIS are an appropriate tool for air-quality monitoring and investigating aerosol optical properties over the YERB. However, the complexity and diversity of the underlying topography of the YERB (mountains, the Loess Plateau, North China plain, etc.), as well as a variety of aerosol sources (frequent coal mining activities in Shanxi Province, among other activities), may increase bias in the satellite aerosol products (e.g., AOD). Therefore, it is recommended that the performance of satellite aerosol products should be evaluated across the YERB before using them for qualitative applications. The main objective of this study is to evaluate the performance of the Aqua-MODIS C6 DT AOD at $3 \mathrm{~km}$ resolution (DT3K) and C6.1 DT AOD at $3 \mathrm{~km}$, DT AOD at $10 \mathrm{~km}$, and DB AOD at 10 $\mathrm{km}$ resolutions (DT3K, DT10K, DB10K, and DTB10K) for different quality flags over the YERB area. The study is organized as follows: Data and methods are described in Section 2, results and discussion are described in Section 3, and finally, conclusions are summarized in Section 4.

\section{Materials and Methods}

\subsection{MODIS C6 and C6.1 Data}

The Aqua-MODIS Level 2 C6 and C6.1 aerosol products were downloaded from the Level-1 and Atmosphere Archive and Distribution System (LAADS) Distributed Active Archive Center (DAAC) (https://ladsweb.modaps.eosdis.nasa.gov/). In comparison to the previous C5.1, significant improvements and modifications were made in the C6 and C6.1 DT and DB algorithms [21,36,39,46,58]. The MODIS C6 and C6.1 AOD retrievals are based on three algorithms: The DT land algorithm, the DT ocean algorithm, and the deep blue (DB) land algorithm [21-23]. The DT land algorithm is designed to retrieve $\mathrm{AOD}$ over vegetation surfaces, whereas the $\mathrm{DB}$ algorithm is designed to retrieve AOD over both bright urban and desert surfaces, as well as vegetation surfaces, but it does not perform 
aerosol inversion over ocean surfaces. These algorithms are unable to provide AOD retrievals over snow-covered surfaces due to their limitations. The specific details of these algorithms have been reported in previous studies [22,24,25,59]. The MODIS C6 aerosol products also provide a set of DT and DB combined data at a $10 \mathrm{~km}$ resolution (DTB10K). The AOD retrievals are provided with respect to quality flags $0,1,2$, and 3, which represent not produced, low-quality, medium-quality, and high-quality retrievals, respectively. In addition, in order to monitor air quality at the city level, C6 and C6.1 also provide the AOD product at a $3 \mathrm{~km}$ resolution (DT3K) based on the DT algorithm. Table 1 shows the scientific data set (SDS) of the Aqua-MODIS C6 and C6.1 AOD products used in this study between April 1, 2002, and December 31, 2014.

Table 1. Scientific Data Set (SDS) of the Aqua-MODIS (Moderate Resolution Imaging Spectrometer) Collection (C6) and C61 aerosol optical depth (AOD) products at $550 \mathrm{~nm}$ used in this study from April 1, 2002 to December 31, 2014.

\begin{tabular}{cccc}
\hline Satellite & Product & Aerosol Optical Depth & Quality Flag \\
\hline Aqua C6 & DT3K & Optical_Depth_Land_And_Ocean & Land_Ocean_Quality_Flag \\
\hline \multirow{2}{*}{ Aqua C6.1 } & DT10K & Optical_Depth_Land_And_Ocean & Land_Ocean_Quality_Flag \\
\cline { 2 - 4 } & DTB10K & $\begin{array}{c}\text { AOD_550_Dark_Target_ } \\
\text { Deep_Blue_Combined }\end{array}$ & $\begin{array}{c}\text { AOD_550_Dark_Target_Deep_ } \\
\text { Blue_Combined_QA_Flag }\end{array}$ \\
\cline { 2 - 4 } & DB10K & $\begin{array}{c}\text { Deep_Blue_Aerosol_Optical_ } \\
\text { Depth_550_Land }\end{array}$ & $\begin{array}{c}\text { Deep_Blue_Aerosol_Optical_ } \\
\text { Depth_550_Land_QA_Flag }\end{array}$ \\
\cline { 2 - 4 } & DT3K & Optical_Depth_Land_And_Ocean & Land_Ocean_Quality_Flag \\
\hline
\end{tabular}

In C6 and C6.1, DTB AOD retrievals were obtained based on DT and DB AOD retrievals. Due to differences in the DT and DB algorithms (pixel selection, surface reflectance estimation, and cloud cover), the spatial coverage of each land AOD product was different. The DTB AOD product aims to improve the spatial coverage while maintaining the quality of the AOD retrievals $[21,25]$, i.e., to retrieve AOD in the same image for those regions where the DT algorithm does not retrieve AOD due to thresholds based on visible-infrared channels and cloud masks [21], as well as where the DB algorithm does not retrieve AOD due to a more stringent cloud mask than DT, which more often erroneously removes cloud-free pixels [22,24].

\subsection{Ground-Based Measurements}

The CARSNET is a commonly used ground-based aerosol observation network which uses CIMEL sunphotometers (CE318) to monitor aerosol optical properties. The CE318 sunphotometer takes direct solar radiation measurements at eight bands and retrieves AOD with a wavelength range from 340 to $1020 \mathrm{~nm}$ but not including $550 \mathrm{~nm}$. More details on the CE318 sunphotometer retrieval algorithm and instrument calibration can be found in references [16,17]. As shown in Table 2 and Figure 1, in order to verify the performance of satellite AOD retrievals over the YERB, CE318 measurements were obtained for Mt. Waliguan (MW), Lanzhou (LZ), Ulate (UL), and Zhengzhou (ZZ) from April 2002 to January 2014. The first location, MW (rural site), is in the upstream (source area) of the YERB, a mountainous site on the east edge of the Qinghai-Xizang Plateau, Qinghai Province, and a global atmosphere watching (GAW) station. The aerosol loading is relatively small in MW. Lanzhou (urban site) is in the upper-middle reach of the YERB, in the center of Lanzhou city, Gansu Province. Ulate (rural site) is in the midstream of the YERB, in northwest Inner Mongolia, though it is in a grass desertification region. Zhengzhou (urban site) is downstream of the YERB, in the center of Zhengzhou city, Henan Province. The CARSNET's quality-assured and cloud-screened data were used. The network follows the same procedure of cloud screening as AERONET Level 2.0 data [17]. 
Table 2. Statistics of the Chinese aerosol remote sensing network (CARSNET) CIMEL sunphotometers CE318 ground sites over the YERB from 2002 to 2014 used in this study.

\begin{tabular}{ccccccc}
\hline Region & CE318 Site & Lon (E) & Lat (N) & Station Type & Quality Flag & Time \\
\hline Upstream & Mt. Waliguan (MW) & 100.92 & 36.28 & Rural & Level 1.5 & $2009.3-2012.4$ \\
Upper and middle reach & Lanzhou (LZ) & 103.88 & 36.05 & Urban & Level 1.5 & $2002.7-2014.1$ \\
Midstream & Ulate (UL) & 108.52 & 41.57 & Rural & Level 1.5 & $2002.4-2005.2$ \\
Downstream & Zhengzhou (ZZ) & 113.68 & 34.78 & Urban & Level 1.5 & $2007.2-2014.1$ \\
\hline
\end{tabular}

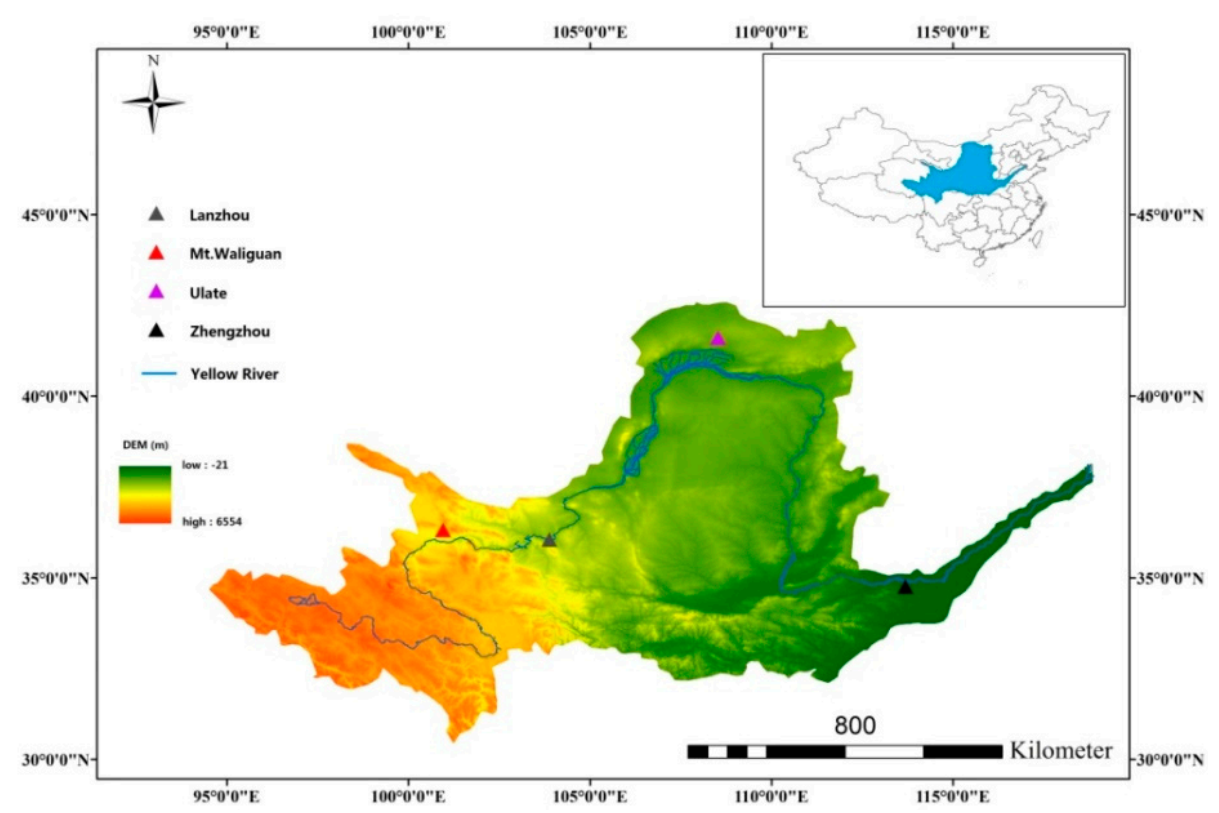

Figure 1. Location of the ground stations (triangle symbols) over the Yellow River basin (YERB).

\subsection{Comparison Methods}

As a sunphotometer does not provide AOD at $550 \mathrm{~nm}$, the AOD at $550 \mathrm{~nm}$ was interpolated using Equations (1) and (2) [11,60]:

$$
\begin{gathered}
\operatorname{AOD}_{\lambda_{i}}=\beta \lambda_{i}^{-\alpha}, \\
\alpha=\frac{\operatorname{In}\left(\frac{\mathrm{AOD}_{\lambda_{1}}}{\mathrm{AOD}_{\lambda_{2}}}\right)}{\operatorname{In}\left(\frac{\lambda_{1}}{\lambda_{2}}\right)}, \beta=\frac{\operatorname{AOD}_{\lambda_{2}}}{\lambda_{2}^{-\alpha}},
\end{gathered}
$$

where $\alpha=$ Angström exponent index, $\beta=$ the turbidity coefficient, and $\lambda_{1}$ and $\lambda_{2}=$ wavelengths at 440 and $870 \mathrm{~nm}$, respectively. For validation purposes, the CE318 AOD values were averaged within \pm 30 minutes of MODIS overpass time, and at least two or more CE318 AOD values were considered. MODIS AOD retrievals were averaged for a spatial region covering $3 \times 3$ pixels centered at the sunphotometer sites [61,62] and at least 2 out of 9 pixels were considered for this purpose. Finally, the linear regressions of the MODIS C6 and C6.1 retrieval against the CE318 AOD measurements were performed over the YERB. The statistical parameters included slope, y-intercept, Pearson's correlation (R), and root mean square error (RMSE, Equation (3)). Furthermore, an uncertainty on the satellite retrieval algorithms was examined based on the expected error (EE, Equation (4)) of the DT algorithm over land, the mean absolute error (MAE, Equation (5)), and the relative mean bias (RMB, Equation (6)).

$$
\begin{gathered}
\text { RMSE }=\sqrt{\frac{1}{n} \sum_{i=1}^{n}\left(\operatorname{AOD}_{(\text {satellite }) i}-\mathrm{AOD}_{(\mathrm{CE} 318) \mathrm{i}}\right)^{2}} \\
\mathrm{EE}= \pm\left(0.05+0.15 \mathrm{AOD}_{\mathrm{CE} 318}\right)
\end{gathered}
$$




$$
\begin{gathered}
\mathrm{MAE}=\frac{1}{\mathrm{n}} \sum_{\mathrm{i}=1}^{\mathrm{n}}\left(\mathrm{AOD}_{(\text {satellite }) \mathrm{i}}-\mathrm{AOD}_{(\mathrm{CE} 318) \mathrm{i}}\right), \\
\mathrm{RMB}=\frac{\overline{\mathrm{AOD}_{\text {satellite }}}}{\overline{\mathrm{AOD}_{\mathrm{CE} 318}}} .
\end{gathered}
$$

The values of RMB $>1$ and RMB $<1$ indicated over- and underestimation in the satellite AOD observations, respectively.

\section{Results and Discussions}

\subsection{Comparison of Aqua-MODIS C6 and C6.1 AOD vs. CE318 AOD}

Figure 2 shows a comparison between collocated DT3K C6 AOD for different quality flags (QF) and CE318 AOD at $550 \mathrm{~nm}$ over the YERB for the period from April 2002 to December 2014. A total of 1488, 1270, and 950 observations of DT 3K C6 data for QF $>0, Q F>1$, and $Q F=3$ were matched with the CE318 data. The QF $>0$ represents the result that contained all quality flags, and the $\mathrm{QF}>1$ represents the result that contained quality flags $\mathrm{QF}=2$ and $\mathrm{QF}=3$. Overall, the comparison results for all statistical variables were good by using each quality flag, i.e., when $\mathrm{QF}>1$, the RMSE was 0.29 , R was 0.81 , and $44.25 \%$ of the groups fell within the expected error (EE). To further investigate the comparison results of the C6 DT3K AOD and the collocated CE318 AOD, the results of every station needed to be studied in detail. As shown in Table 3, however, the matchup results for the MW and LZ stations were poor, and with the increase in QF, the results were not improved. As shown in Figure 2, the value of correlation coefficient $\mathrm{R}$ was within the range of $0.81-0.82$, and the proportion of matching data falling within the EE was $42.74-44.96 \%$. This phenomenon indicated that, despite the good correlation coefficient, the C6 DT3K products still could not meet the demand of the EE (i.e., the proportion of matching data falling within the EE was $66 \%$ ). At the same time, the value of the RMB was between 1.00 and 1.01, indicating that the value of C6 DT3K was almost the same as CE318 AOD in the YERB region. The reason for this phenomenon may be that the MW site had serious overestimations with large RMB values ranging from 1.36 to 1.64 , whereas the LZ site had a large number of underestimated phenomena (the RMB values were small, and the numerical range was from 0.61 to 0.62 ). The two phenomena were combined to form complementation, which would cause almost the same results of the two AOD products' estimations in the whole YERB region. The phenomenon of overestimation or underestimation is mainly caused by the overestimation or underestimation of the surface albedo in the visible light band in the process of satellite AOD retrieval, especially in urban and suburban areas [21]. As shown clearly in Table 3, the C6 DT3K AOD had relatively good verification results at the $\mathrm{ZZ}$ station, with $\mathrm{R}=0.84-0.85, \mathrm{RMB}=1.21-1.23$, $\mathrm{MAE}=0.16-0.17$, and $51.63-52.26 \%$ retrievals within the EE.
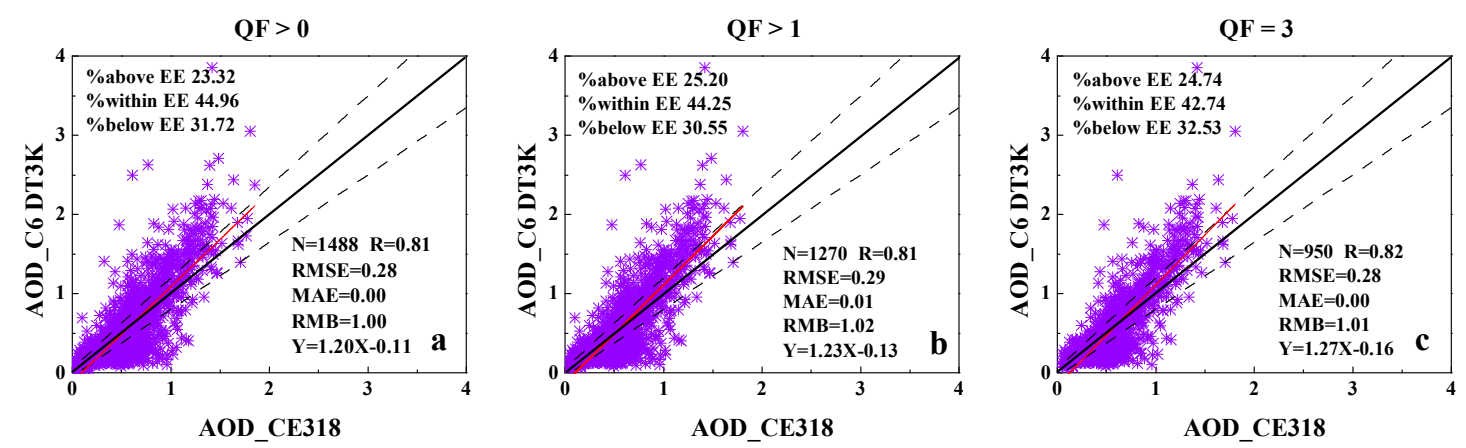

Figure 2. Comparison of the C6 DT AOD retrievals at $3 \mathrm{~km}$ (DT3K) with CE318 AOD observations at $550 \mathrm{~nm}$ over the YERB for the period of July 1, 2002 to December 31, 2014. The DT3K AOD retrievals are classified by all $(\mathrm{QF}>0,(\mathbf{a}))$, medium $(\mathrm{QF}>1,(\mathbf{b}))$, and high $(\mathrm{QF}=3,(\mathbf{c}))$ quality flags. The black straight line is the 1:1 line, the red straight line is the regression line, and the expected error (EE) envelope is within the dashed lines. 
Table 3. Comparison of the C6 DT3K AOD products at $550 \mathrm{~nm}(\mathrm{QF}>0, \mathrm{QF}>1$, and $\mathrm{QF}=3)$ with CE318 AOD observations at $550 \mathrm{~nm}$ at Mt. Waliguan (MW), Lanzhou (LZ), Ulate (UL), and Zhengzhou (ZZ) for the period of July 1, 2002 to December 31, 2014, where ALL represents all stations' data.

\begin{tabular}{cccccccccc}
\hline Station & QF & N & Slope & Y-int & R & MAE & RMB & RMSE & Within EE\% \\
\hline \multirow{4}{*}{ MW } & QF $>0$ & 127 & 0.84 & 0.07 & 0.62 & 0.05 & 1.36 & 0.07 & 65.35 \\
& QF $>1$ & 88 & 0.70 & 0.10 & 0.45 & 0.06 & 1.48 & 0.08 & 57.95 \\
& QF $=3$ & 41 & 0.86 & 0.10 & 0.43 & 0.08 & 1.64 & 0.09 & 53.66 \\
& QF $>0$ & 603 & 0.40 & 0.11 & 0.43 & -0.20 & 0.61 & 0.15 & 28.69 \\
LZ & QF $>1$ & 508 & 0.38 & 0.12 & 0.45 & -0.20 & 0.61 & 0.13 & 30.12 \\
& QF $=3$ & 410 & 0.42 & 0.10 & 0.48 & -0.19 & 0.62 & 0.13 & 30.49 \\
& QF $>0$ & 94 & 0.87 & 0.04 & 0.78 & 0.00 & 1.02 & 0.12 & 70.21 \\
UL & QF $>1$ & 42 & 0.94 & 0.05 & 0.76 & 0.03 & 1.14 & 0.13 & 66.67 \\
& QF $=3$ & - & - & - & - & - & - & - & - \\
& QF $>0$ & 664 & 1.27 & -0.03 & 0.85 & 0.17 & 1.23 & 0.28 & 52.26 \\
& QF $>1$ & 632 & 1.28 & -0.03 & 0.84 & 0.17 & 1.23 & 0.28 & 52.22 \\
& QF $=3$ & 490 & 1.26 & -0.03 & 0.85 & 0.16 & 1.21 & 0.28 & 51.63 \\
& QF $>0$ & 1488 & 1.20 & -0.11 & 0.81 & 0.00 & 1.00 & 0.28 & 44.96 \\
& QF $>1$ & 1270 & 1.23 & -0.13 & 0.81 & 0.01 & 1.02 & 0.29 & 44.25 \\
& QF $=3$ & 950 & 1.27 & -0.16 & 0.82 & 0.00 & 1.01 & 0.28 & 42.74 \\
\hline
\end{tabular}

Figure 3 shows the comparative results of C6.1 DT3K at $550 \mathrm{~nm}$ and CE318 AOD at $550 \mathrm{~nm}$ over the YERB. A total of 1307, 1270, and 950 matchups were successfully obtained for QF $>0, Q F>1$, and $\mathrm{QF}=3$, respectively. When the QF of C6.1 DT3K was 3, the comparative results of the whole YERB were very good, with an R-value of 0.82 , and $42.74 \%$ of the C6.1 The DT3K AOD data were within the range of the EE. In addition, the value of the RMB was 1.01, indicating that the satellite products were overvalued only by $1 \%$. This indicates that the RMB is independent of the quality flag. Through a site-by-site detailed experiment (Table 4), the C6.1 DT3K products were overestimated by $36-64 \%, 2-32 \%$, and $22-23 \%$ in the MW, UL, and ZZ sites, respectively. However, at the LZ station, the satellite products were undervalued by $38-39 \%$ and the MAE values were from -0.20 to -0.19 . Similar experimental results are also mentioned in reference [21], and those results showed that the C6 DT product was slightly underestimated during low aerosol loadings (AOD $<0.3$ ).

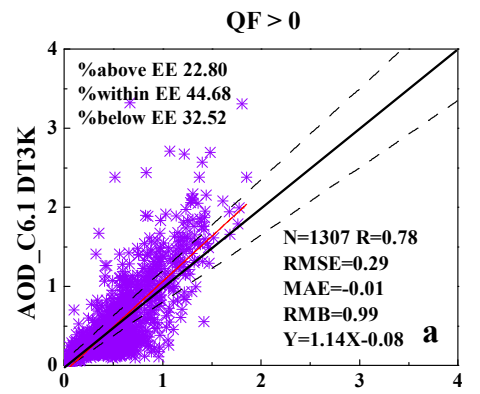

AOD_CE318

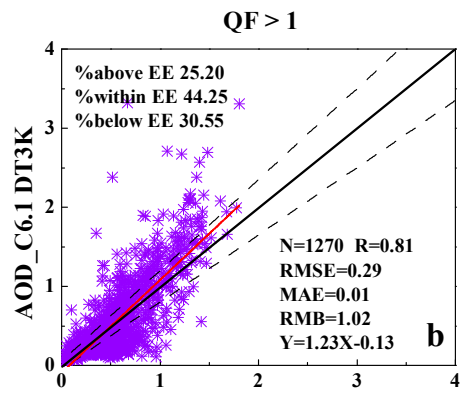

AOD_CE318

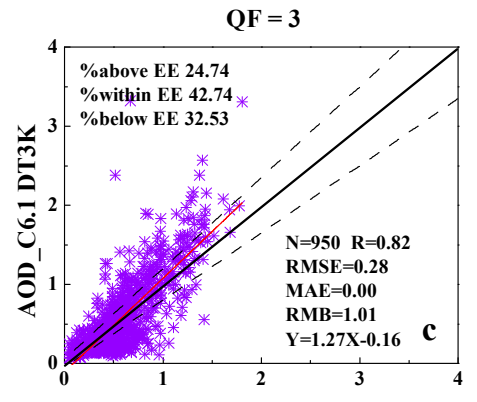

AOD_CE318

Figure 3. Comparison between the C6.1 DT3K AOD product at $550 \mathrm{~nm}$ and the CE318 AOD observations at $550 \mathrm{~nm}$ over the YERB for the period of July 1, 2002 to December 31, 2014. The DT3K AOD retrievals were classified by all $(\mathrm{QF}>0,(\mathbf{a}))$, medium $(\mathrm{QF}>1,(\mathbf{b}))$, and high $(\mathrm{QF}=3,(\mathbf{c}))$ quality flags. The black straight line is the 1:1 line, the red straight line is the regression line, and the EE envelope is within the dashed lines. 
Table 4. Comparison of the C6.1 DT3K AOD product at $550 \mathrm{~nm}(\mathrm{QF}>0, \mathrm{QF}>1$, and $\mathrm{QF}=3)$ against the CE318 AOD observations at $550 \mathrm{~nm}$ at MW, LZ, UL, and ZZ for the period of July 1, 2002 to December 31, 2014, where ALL represents all stations' data.

\begin{tabular}{cccccccccc}
\hline Station & QF & N & Slope & Y-int & R & MAE & RMB & RMSE & Within EE\% \\
\hline \multirow{4}{*}{ MW } & QF $>0$ & 127 & 0.84 & 0.07 & 0.62 & 0.05 & 1.36 & 0.07 & 65.35 \\
& QF $>1$ & 88 & 0.70 & 0.10 & 0.45 & 0.06 & 1.48 & 0.08 & 57.95 \\
& QF $=3$ & 41 & 0.86 & 0.10 & 0.43 & 0.08 & 1.64 & 0.09 & 53.66 \\
& QF $>0$ & 532 & 0.39 & 0.11 & 0.44 & -0.20 & 0.61 & 0.14 & 29.32 \\
& QF $>1$ & 451 & 0.37 & 0.12 & 0.45 & -0.19 & 0.62 & 0.13 & 30.82 \\
& QF $=3$ & 365 & 0.39 & 0.11 & 0.48 & -0.19 & 0.62 & 0.12 & 32.05 \\
UL & QF $>0$ & 94 & 0.87 & 0.04 & 0.78 & 0.00 & 1.02 & 0.12 & 70.21 \\
& QF $>1$ & 42 & 0.94 & 0.05 & 0.76 & 0.03 & 1.14 & 0.13 & 66.67 \\
& QF $=3$ & 9 & 1.24 & 0.02 & 0.77 & 0.09 & 1.32 & 0.13 & 66.67 \\
ZZ & QF $>0$ & 554 & 1.21 & 0.02 & 0.81 & 0.16 & 1.23 & 0.31 & 50.36 \\
& QF $>1$ & 521 & 1.21 & 0.02 & 0.81 & 0.16 & 1.23 & 0.31 & 50.29 \\
& QF $=3$ & 402 & 1.17 & 0.03 & 0.80 & 0.16 & 1.22 & 0.30 & 50.25 \\
ALL & QF $>0$ & 1307 & 1.14 & -0.08 & 0.78 & -0.01 & 0.99 & 0.29 & 44.68 \\
& QF $>1$ & 1270 & 1.23 & -0.13 & 0.81 & 0.01 & 1.02 & 0.29 & 44.25 \\
& QF $=3$ & 950 & 1.27 & -0.16 & 0.82 & 0.00 & 1.01 & 0.28 & 42.74
\end{tabular}

Figure 4 shows the comparative results of C6.1 DT10K at $550 \mathrm{~nm}$ and CE318 AOD at $550 \mathrm{~nm}$. A total of 1674, 1085, and 139 matchups were successfully obtained for $Q F>0, Q F>1$, and $Q F=3$, respectively. Compared with $\mathrm{QF}>0$ and $\mathrm{QF}>1$, the C6.1 DT10K AOD with QF $=3$ had little data volume, with a total amount of only 139, which was almost the contribution of the LZ station; the matching result of $\mathrm{C} 6.1 \mathrm{DT} 10 \mathrm{~K}$ with $\mathrm{QF}=3$ was not good $(\mathrm{R}=0.58)$. However, when the $\mathrm{C} 6.1$ DT10K retrievals were in $\mathrm{QF}>0$ or $\mathrm{QF}>1$, the matching result was good, with high $\mathrm{R}$-values (0.78-0.81), nearly $43.31-43.41 \%$ of the AOD retrievals falling into the EE, and an RMB of 1.05-1.07, resulting in only a 5-7\% overestimation compared to the CE318 AOD. As shown in Table 5, the C6.1 DT10K AOD was overestimated by $50-78 \%, 25-42 \%$, and $22-28 \%$ in MW, UL, and ZZ stations, respectively. However, the C6.1 DT10K AOD was underestimated by $32-47 \%$ at the LZ station. This phenomenon was similar to the case of C6.1 DT3K (Figure 3). The reason for this might be the low AOD values in the LZ site (nearly $70 \%$ of the CE318 AOD observations were less than 0.3 ). A similar result is also reported in reference [21], i.e., the C6 DT10K product tended to slightly underestimate AOD retrievals in conditions with low aerosol loadings $(\mathrm{AOD}<0.3)$ over global land.
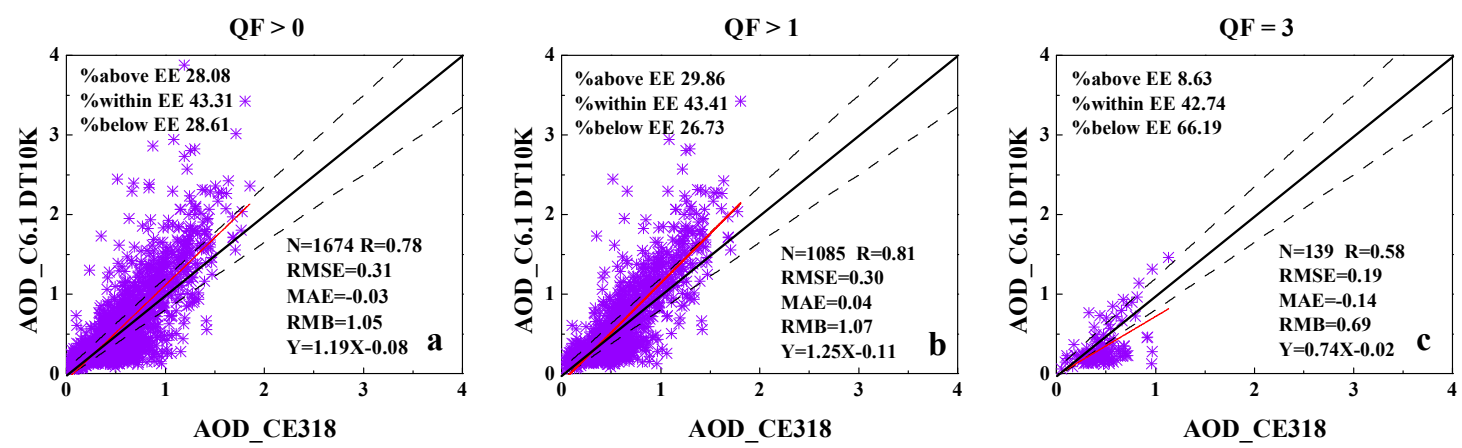

Figure 4. Validation of the C6.1 DT10K AOD product at $550 \mathrm{~nm}$ against the CE318 AOD observations at $550 \mathrm{~nm}$ over the YERB for the period of July 1, 2002 to December 31, 2014. The DT3K AOD retrievals are classified by all $(\mathrm{QF}>0,(\mathbf{a}))$, medium $(\mathrm{QF}>1,(\mathbf{b}))$, and high $(\mathrm{QF}=3,(\mathbf{c}))$ quality flags. The black straight line is the 1:1 line, the red straight line is the regression line, and the EE envelope is within the dashed lines. 
Table 5. Comparison of the C6.1 DT10K AOD product (QF > 0, QF $>1$, and $\mathrm{QF}=3$ ) against the CE318 AOD observations at $550 \mathrm{~nm}$ at MW, LZ, UL, and ZZ for the period of July 1, 2002 to December 31, 2014, where ALL represents all stations' data.

\begin{tabular}{cccccccccc}
\hline Station & QF & N & Slope & Y-int & R & MAE & RMB & RMSE & Within EE\% \\
\hline \multirow{4}{*}{ MW } & QF $>0$ & 111 & 0.91 & 0.09 & 0.54 & 0.08 & 1.62 & 0.08 & 50.45 \\
& QF $>1$ & 53 & 0.66 & 0.14 & 0.38 & 0.10 & 1.78 & 0.09 & 37.74 \\
& QF $=3$ & 6 & 1.36 & 0.02 & 0.81 & 0.07 & 1.50 & 0.07 & 66.67 \\
& QF $>0$ & 721 & 0.43 & 0.13 & 0.46 & -0.17 & 0.68 & 0.15 & 35.92 \\
& QF $>1$ & 410 & 0.52 & 0.07 & 0.54 & -0.18 & 0.66 & 0.14 & 36.34 \\
& QF $=3$ & 108 & 0.21 & 0.15 & 0.34 & -0.21 & 0.53 & 0.09 & 18.52 \\
UL & QF $>0$ & 145 & 1.12 & 0.03 & 0.77 & 0.06 & 1.25 & 0.14 & 58.62 \\
& QF $>1$ & 39 & 1.29 & 0.03 & 0.73 & 0.10 & 1.42 & 0.17 & 46.15 \\
& QF $=3$ & 2 & 0.23 & 0.20 & 1.00 & -0.01 & 0.95 & 0.00 & 0.00 \\
ZZ & QF $>0$ & 697 & 1.25 & 0.02 & 0.79 & 0.21 & 1.28 & 0.35 & 46.63 \\
& QF $>1$ & 583 & 1.23 & 0.01 & 0.82 & 0.19 & 1.25 & 0.31 & 48.71 \\
& QF $=3$ & 23 & 1.30 & -0.05 & 0.90 & 0.13 & 1.22 & 0.16 & 47.83 \\
ALL & QF $>0$ & 1674 & 1.19 & -0.08 & 0.78 & 0.03 & 1.05 & 0.31 & 43.31 \\
& QF $>1$ & 1085 & 1.25 & -0.11 & 0.81 & 0.04 & 1.07 & 0.30 & 43.41 \\
& QF $=3$ & 139 & 0.74 & -0.02 & 0.58 & -0.14 & 0.69 & 0.19 & 25.18 \\
\hline
\end{tabular}

Figure 5 shows the validation of C6.1 DB10K at $550 \mathrm{~nm}$ and CE318 AOD at $550 \mathrm{~nm}$ in the YERB area. As shown in the figure, a total of 1861, 1163, and 577 C6.1 DB10K-CE318 matchups were available for $\mathrm{QF}>0, \mathrm{QF}>1$, and $\mathrm{QF}=3$, respectively. When $\mathrm{QF}>0$, the C6.1 DB10K AOD was well matched with the CE318 AOD, i.e., the R-value was 0.78 and the percentage within the EE was $39.28 \%$. As shown in Figure $5 \mathrm{a}$, when $\mathrm{QF}>0$, the $\mathrm{C} 6.1 \mathrm{DB} 10 \mathrm{~K}$ was slightly underestimated and accompanied by a negative MAE (-0.11). In addition, as shown in Figure $5 c$, when $Q F=3$, the percentage of C6.1 DB10K falling into the $\mathrm{EE}$ was approximately $35.88 \%$ and the $\mathrm{RMB}=0.63$, indicating that the satellite product was undervalued by $37 \%$. According to the evaluation results of each independent site in Table 6 , the RMB values almost were $<0$ over every station, and the C6.1 DB10K products showed different degrees of underestimation under different quality labels in each site, which is a result similar to the results of the YRB. In terms of the evaluations over individual sites of the YRB, the DB10K tend to underestimate AOD retrievals for all quality flags in the Hefei, Wuhan, and Kunming sites [49,50].
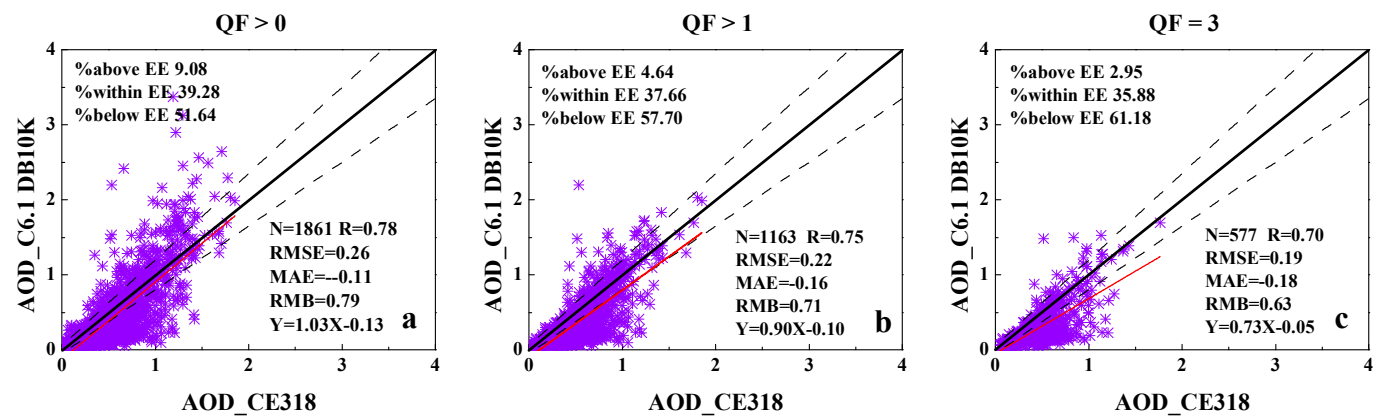

Figure 5. Validation of the C6.1 Deep Blue AOD retrievals at $10 \mathrm{~km}$ resolution (DB10K) against the CE318 AOD observations at $550 \mathrm{~nm}$ over the YERB for the period of July 1, 2002 to December 31, 2014. The DT3K AOD retrievals are classified by all $(\mathrm{QF}>0,(\mathbf{a}))$, medium $(\mathrm{QF}>1,(\mathbf{b}))$, and high $(\mathrm{QF}=3,(\mathbf{c}))$ quality flags. The black straight line is the 1:1 line, the red straight line is the regression line, and the EE envelope is within the dashed lines. 
Table 6. Comparison of the C6.1 DB10K AOD products at $550 \mathrm{~nm}(\mathrm{QF}>0, \mathrm{QF}>1$, and $\mathrm{QF}=3)$ against the CE318 AOD observations at $550 \mathrm{~nm}$ at MW, LZ, UL, and ZZ for the period of July 1, 2002 to December 31, 2014, where ALL represents all stations' data.

\begin{tabular}{cccccccccc}
\hline Station & QF & N & Slope & Y-int & R & MAE & RMB & RMSE & Within EE\% \\
\hline \multirow{4}{*}{ MW } & QF $>0$ & 111 & 0.59 & 0.02 & 0.66 & -0.03 & 0.73 & 0.06 & 74.77 \\
& QF $>1$ & 6 & -0.12 & 0.04 & 0.31 & -0.02 & 0.60 & 0.01 & 83.33 \\
& QF $=3$ & - & - & - & - & - & - & - & - \\
\multirow{4}{*}{ LZ } & QF $>0$ & 843 & 0.35 & 0.09 & 0.46 & -0.26 & 0.52 & 0.13 & 16.49 \\
& QF $>1$ & 511 & 0.34 & 0.06 & 0.49 & -0.30 & 0.45 & 0.11 & 9.20 \\
& QF $=3$ & 231 & 0.33 & 0.03 & 0.59 & -0.35 & 0.38 & 0.09 & 1.73 \\
UL & QF $>0$ & 221 & 0.77 & 0.00 & 0.77 & -0.05 & 0.77 & 0.09 & 55.66 \\
& QF $>1$ & 151 & 0.71 & 0.00 & 0.72 & -0.06 & 0.70 & 0.09 & 53.64 \\
& QF $=3$ & 79 & 0.42 & 0.02 & 0.69 & -0.09 & 0.54 & 0.06 & 48.10 \\
ZZ & QF $>0$ & 686 & 1.20 & -0.11 & 0.82 & 0.03 & 1.05 & 0.30 & 56.27 \\
& QF $>1$ & 495 & 1.06 & -0.07 & 0.85 & -0.04 & 0.94 & 0.21 & 61.62 \\
& QF $=3$ & 267 & 1.06 & -0.09 & 0.89 & -0.06 & 0.89 & 0.15 & 61.80 \\
ALL & QF $>0$ & 1861 & 1.03 & -0.13 & 0.78 & -0.11 & 0.79 & 0.26 & 39.28 \\
& QF $>1$ & 1163 & 0.90 & -0.10 & 0.75 & -0.16 & 0.71 & 0.22 & 37.66 \\
& QF $=3$ & 577 & 0.73 & -0.05 & 0.70 & -0.18 & 0.63 & 0.19 & 35.88 \\
\hline
\end{tabular}

Figure 6 reports the validation of the C6.1 DTB10K at $550 \mathrm{~nm}$ against the CE318 AOD retrievals at $550 \mathrm{~nm}$ for $\mathrm{QF}>0(\mathrm{~N}=1516), \mathrm{QF}>1(\mathrm{~N}=940)$, and $\mathrm{QF}=3(\mathrm{~N}=446)$. The C6.1 DTB10K AOD was a set of combined data by utilizing the DT and DB algorithms at different surface reflectance. The product can be retrieved over vegetated and bright land surfaces. Compared to the other high-quality Aqua-MODIS C6.1 products (Figures $4 \mathrm{c}$ and $5 \mathrm{c})$, the high $\mathrm{QF}(\mathrm{QF}=3) \mathrm{C} 6.1 \mathrm{DTB} 10 \mathrm{~K}$ retrievals performed similarly to the others, i.e., the R-value and the percentage within the EE (Figure $6 \mathrm{c}$ ) were 0.74 and $34.75 \%$, respectively. Table 7 shows the statistical results of each individual station over the YERB, and the C6.1 DTB10K AOD of the LZ station was underestimated by approximately $61 \%$ when $\mathrm{QF}=3$, accompanied by the appearance of a negative MAE (-0.33). At the UL station, the C6.1 DTB10K AOD was also undervalued by approximately $45 \%$, also with the emergence of a negative MAE $(-0.08)$ when $\mathrm{QF}=3$. The results at the MW and ZZ stations were better than those at the LZ and UL sites. The C6.1 DTB10K AOD of the MW station was slightly overestimated by approximately $12 \%$ when QF $>1$, accompanied by the appearance of a positive MAE (0.01). The C6.1 DTB10K AOD of the ZZ station was also slightly overestimated by approximately $15 \%$ when $\mathrm{QF}=3$, accompanied by the appearance of a positive MAE (0.09). Overall, the results (Tables 3-6) showed that the percentage with the EE for the individual site was greater than all the sites when combined together. This suggests that, currently, no MODIS aerosol product is suitable for the whole YERB region, and it is a challenging task to obtain high-quality AOD retrievals.
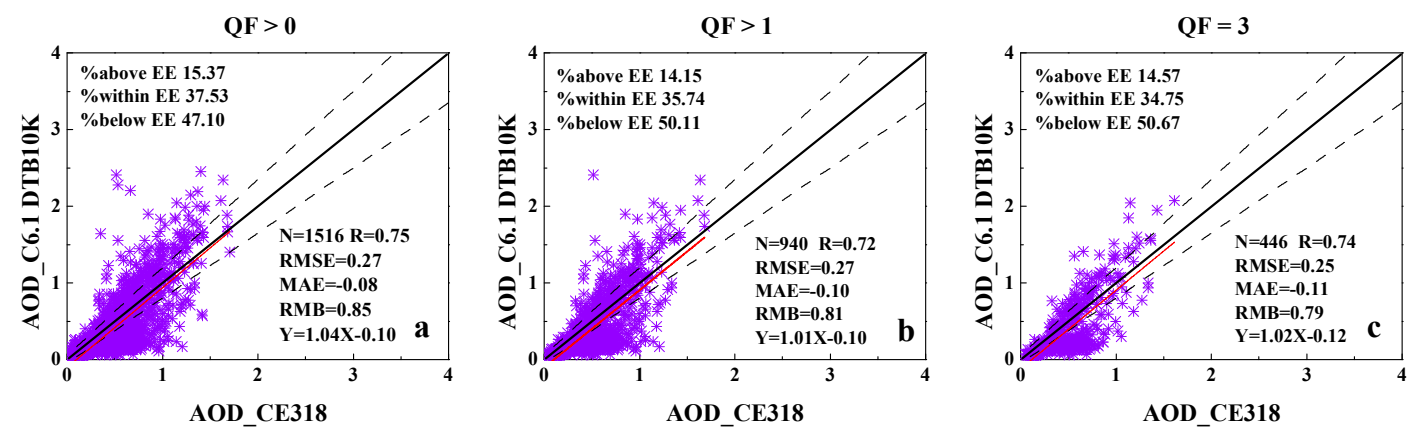

Figure 6. Validation of the C6.1 DTB10K AOD product at $550 \mathrm{~nm}$ against the CE318 AOD observations at $550 \mathrm{~nm}$ over the YERB for the period of July 1, 2002 to December 31, 2014. The DT3K AOD retrievals were classified by all $(\mathrm{QF}>0,(\mathbf{a}))$, medium $(\mathrm{QF}>1,(\mathbf{b}))$, and high $(\mathrm{QF}=3,(\mathbf{c}))$ quality flags. The black straight line is the 1:1 line, the red straight line is the regression line, and the EE envelope is within the dashed lines. 
Table 7. Validation of the C6.1 DTB10K AOD product at $550 \mathrm{~nm}(\mathrm{QF}>0, \mathrm{QF}>1$, and $\mathrm{QF}=3)$ against the CE318 AOD observations at $550 \mathrm{~nm}$ at MW, LZ, UL, and ZZ for the period of 1 July, 2002 to 31 December, 2014, where ALL represents all stations' data.

\begin{tabular}{cccccccccc}
\hline Station & QF & N & Slope & Y-int & R & MAE & RMB & RMSE & Within EE\% \\
\hline \multirow{4}{*}{ MW } & QF $>0$ & 40 & 0.81 & 0.07 & 0.82 & 0.04 & 1.32 & 0.06 & 62.50 \\
& QF $>1$ & 7 & 0.94 & 0.02 & 0.89 & 0.01 & 1.12 & 0.03 & 100.00 \\
& QF $=3$ & - & - & - & - & - & - & - & - \\
& QF $>0$ & 707 & 0.37 & 0.09 & 0.48 & -0.26 & 0.53 & 0.12 & 16.83 \\
& QF $>1$ & 419 & 0.30 & 0.08 & 0.49 & -0.30 & 0.45 & 0.10 & 7.40 \\
& QF $=3$ & 180 & 0.30 & 0.05 & 0.54 & -0.33 & 0.39 & 0.08 & 3.33 \\
& QF $>0$ & 199 & 0.81 & -0.01 & 0.80 & -0.06 & 0.74 & 0.09 & 57.29 \\
UL & QF $>1$ & 126 & 0.71 & -0.01 & 0.74 & -0.06 & 0.68 & 0.08 & 57.94 \\
& QF $=3$ & 70 & 0.48 & 0.01 & 0.72 & -0.08 & 0.55 & 0.05 & 50.00 \\
& QF $>0$ & 570 & 1.16 & 0.01 & 0.82 & 0.12 & 1.17 & 0.27 & 54.56 \\
ZZ & QF $>1$ & 388 & 1.17 & 0.00 & 0.83 & 0.11 & 1.16 & 0.24 & 57.99 \\
& QF $=3$ & 196 & 1.17 & -0.01 & 0.87 & 0.09 & 1.15 & 0.20 & 58.16 \\
ALL & QF $>0$ & 1516 & 1.04 & -0.10 & 0.75 & -0.08 & 0.85 & 0.27 & 37.53 \\
& QF $>1$ & 940 & 1.01 & -0.10 & 0.72 & -0.10 & 0.81 & 0.27 & 35.74 \\
& QF $=3$ & 446 & 1.02 & -0.12 & 0.74 & -0.11 & 0.79 & 0.25 & 34.75 \\
\hline
\end{tabular}

Figure 7 shows the box diagram of bias $\left(\mathrm{AOD}_{\text {satellite }}-\mathrm{AOD}_{\mathrm{CE} 318}\right)$ between the high-quality MODIS $\mathrm{AOD}(\mathrm{QF}=2,3)$ retrievals and the CE318 AOD retrievals. In general, bias of DT3K C6 (Figure 7a), DT10K C6.1 (Figure 7b), and DT3K C6.1 (Figure 7e) was often greater than 0, and this bias was increased with the increase in the CE318 AOD. These results are consistent with the previous regional and global evaluations [23,38]. In summary, DT C6 and C6.1 AOD retrievals were generally overestimated over the YERB. However, an opposite trend was observed on the basis of DTB10K C6.1 (Figure 7c) and the C6.1 DB10K AOD (Figure 7d) retrievals. Generally, the DB10K C6.1 AOD retrievals tended to be underestimated. The DTB10K C6.1 AOD retrievals tended to be underestimated when the CE318 AOD $<1.1$, and they tended to be slightly overestimated when AOD > 1.1. Similar findings were also reported over the YRB [49].
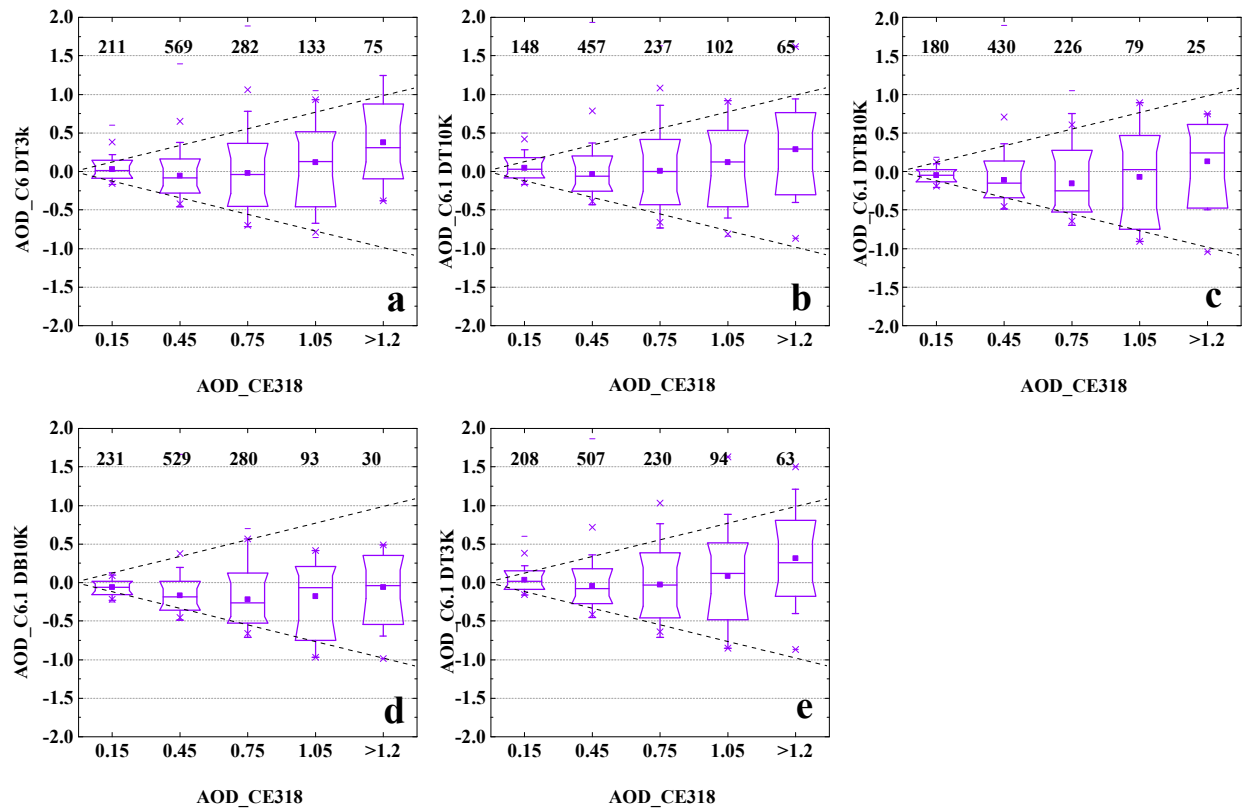

Figure 7. Box plots of the high-quality $(\mathrm{QF}=2,3)$ Aqua-MODIS C6 and C6.1 retrieval biases at $550 \mathrm{~nm}$ (AOD satellite-AOD CE318) against the CE318 AOD observations at $550 \mathrm{~nm}$ over the YERB for the period of July 1, 2002 to December 31, 2014. The EE envelopes are within the dashed lines. The number above each box refers to the corresponding matchups in the different intervals of the CE318 AOD (0-0.3, 0.3-0.6, 0.6-0.9, 0.9-1.2, and >1.2). The C6 DT3K, C6.1 DT10K, C6.1 DTB10K, C6.1 DB10K, and C6.1 DT3K retrieval biases are presented in (a)-(e), respectively. 


\subsection{Seasonal Variation of $A O D$ Retrieval Bias}

Figure 8 reveals the seasonal variation of the high-quality $(\mathrm{QF}=2,3)$ satellite AOD retrievals and CE318 AOD observations for the MW, LZ, UL, and ZZ sites. Over each site, MODIS AOD values were observed during spring and summer, whereas low values were observed during autumn and winter. However, opposite behavior of the CE318 AOD values was observed. Similar results were also observed over the WH site located in the YRB $[49,60]$. Because many deserts exist in north-western China and frequent sandstorms can appear in the YERB in spring, the result is an increase in aerosol loadings and higher AOD values. In addition, summer is the crop harvest season in the YERB, and crop straw burning in local regions also aggravates the emissions of aerosols, thus leading to an increase in the AOD value. The reason for the AOD characteristics of the LZ CE318 might be due to the differences in aerosol type, surface reflectance, and local climate [59]. The LZ site often had high sunphotometer AOD values, which is because LZ is in the north-western region of China, which has a semiarid climate and many yearly dust events; both of which lead to a high aerosol load and high AOD values [63].
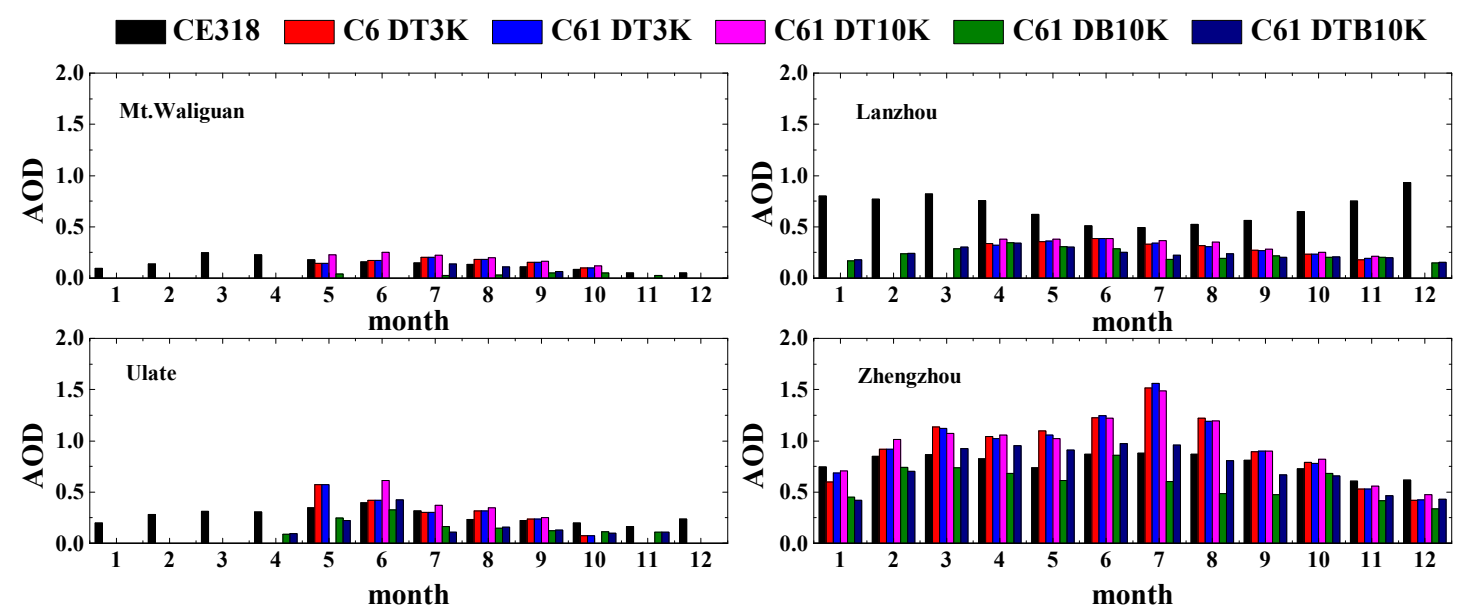

Figure 8. Seasonal and annual variation of the Aqua-MODIS C6 and C6.1 $\mathrm{AOD}$ retrievals ( $\mathrm{QF}=2,3$ ) at $550 \mathrm{~nm}$ and the CE318 AOD observations at $550 \mathrm{~nm}$, respectively, at MW, LZ, UL, and ZZ for the period of 1 July, 2002 to 31 December, 2014.

To deeply study the influence of seasonal factors on the satellite AOD products, the daily mean Aqua-MODIS $\mathrm{C} 6$ and $\mathrm{C} 6.1$ retrieval biases $\left(\mathrm{AOD}_{\text {satellite }}-\mathrm{AOD}_{\mathrm{CE} 318}\right)$ at $550 \mathrm{~nm}$ were investigated over MW (Figure 9), LZ (Figure 10), UL (Figure 11), and ZZ (Figure 12) from July 1, 2002 to December 31, 2014. From Figures 9-12, the biases of the Aqua-MODIS C6 and C6.1 DT (3K and 10K) were positive almost all year round except for the LZ station. The absolute values of the biases increased in winter in LZ. In contrast, the C6.1 DB10K AOD biases were almost an underestimation in every season except for the ZZ station. Similar seasonal variations in satellite product biases have also occurred in eastern China [59] and in the YRB [49]. In addition, the bias values of the MODIS AOD products did not show obvious seasonal variation except for LZ. 


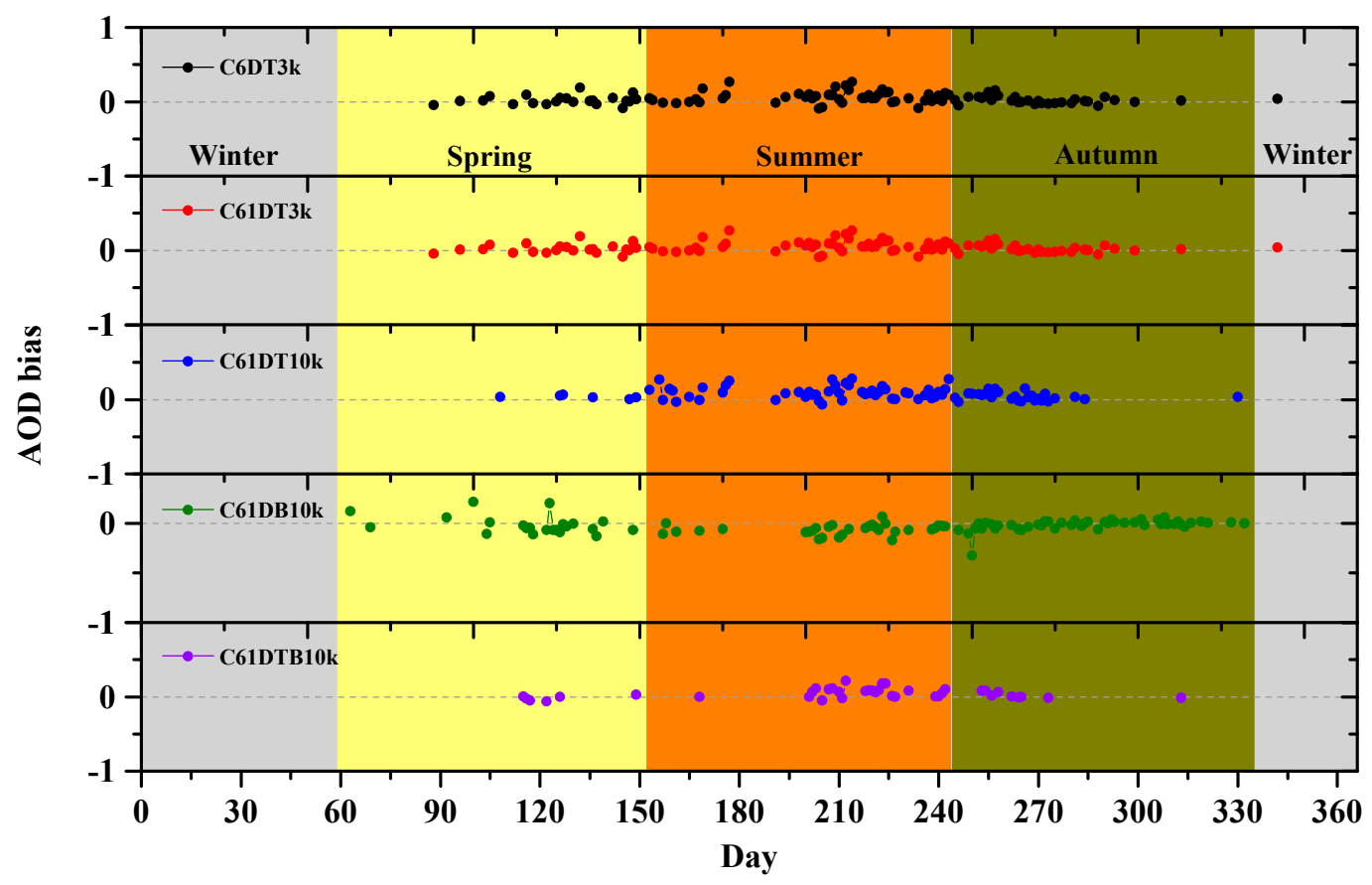

Figure 9. Seasonal variation of the Aqua-MODIS C6 and C6.1 AOD retrieval biases (QF $>0)$ of the CE318 AOD observations at $550 \mathrm{~nm}$ at the MW site. Note that the y-axis refers to the multi-year daily mean AOD bias values for the period of 1 July, 2002 to 31 December, 2014.

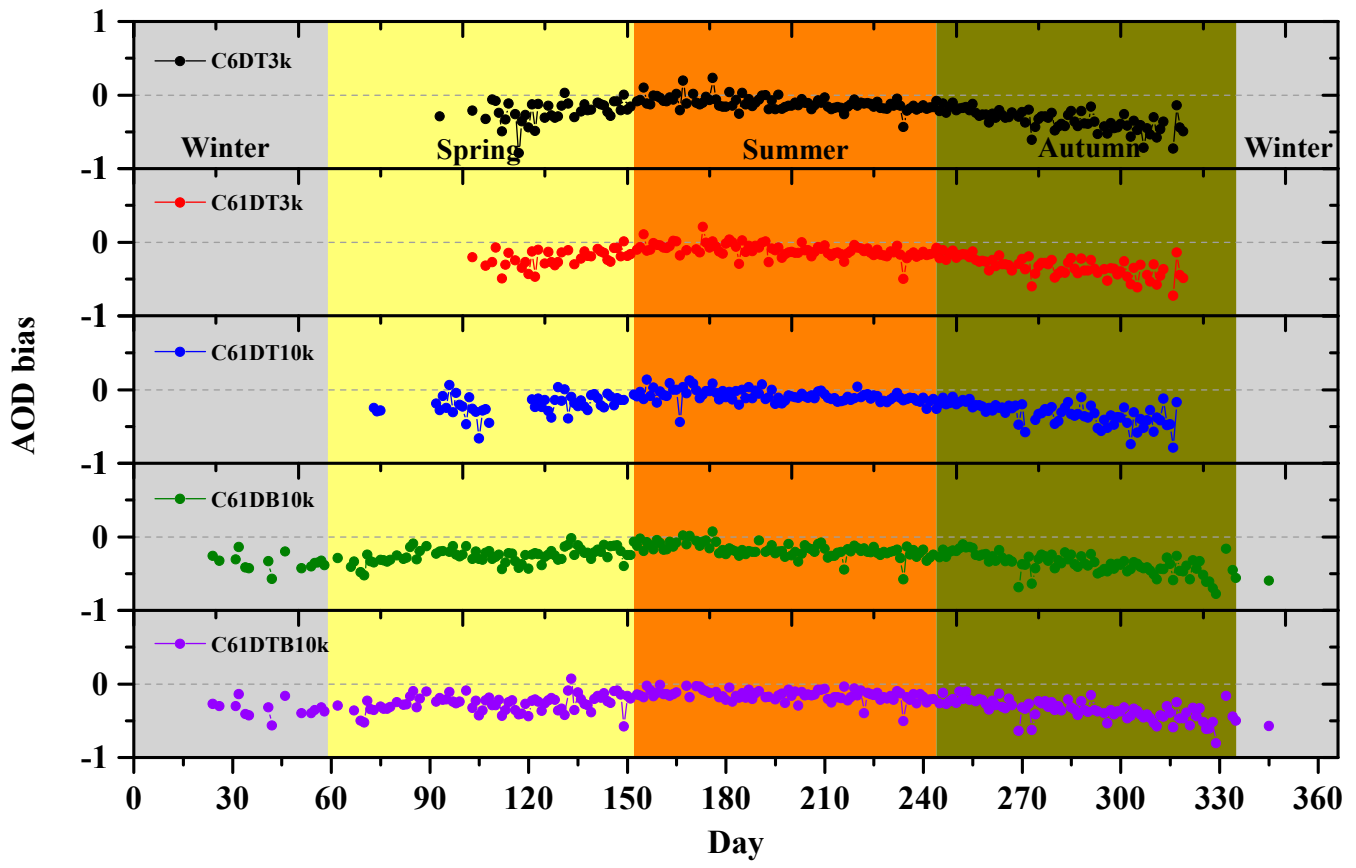

Figure 10. Seasonal variation of the Aqua-MODIS C6 and C6.1 AOD retrieval biases (QF $>0)$ of the CE318 AOD observations at $550 \mathrm{~nm}$ at the $\mathrm{LZ}$ site. Note that the $\mathrm{y}$-axis refers to the multi-year daily mean AOD bias values for the period of 1 July, 2002 to 31 December, 2014. 


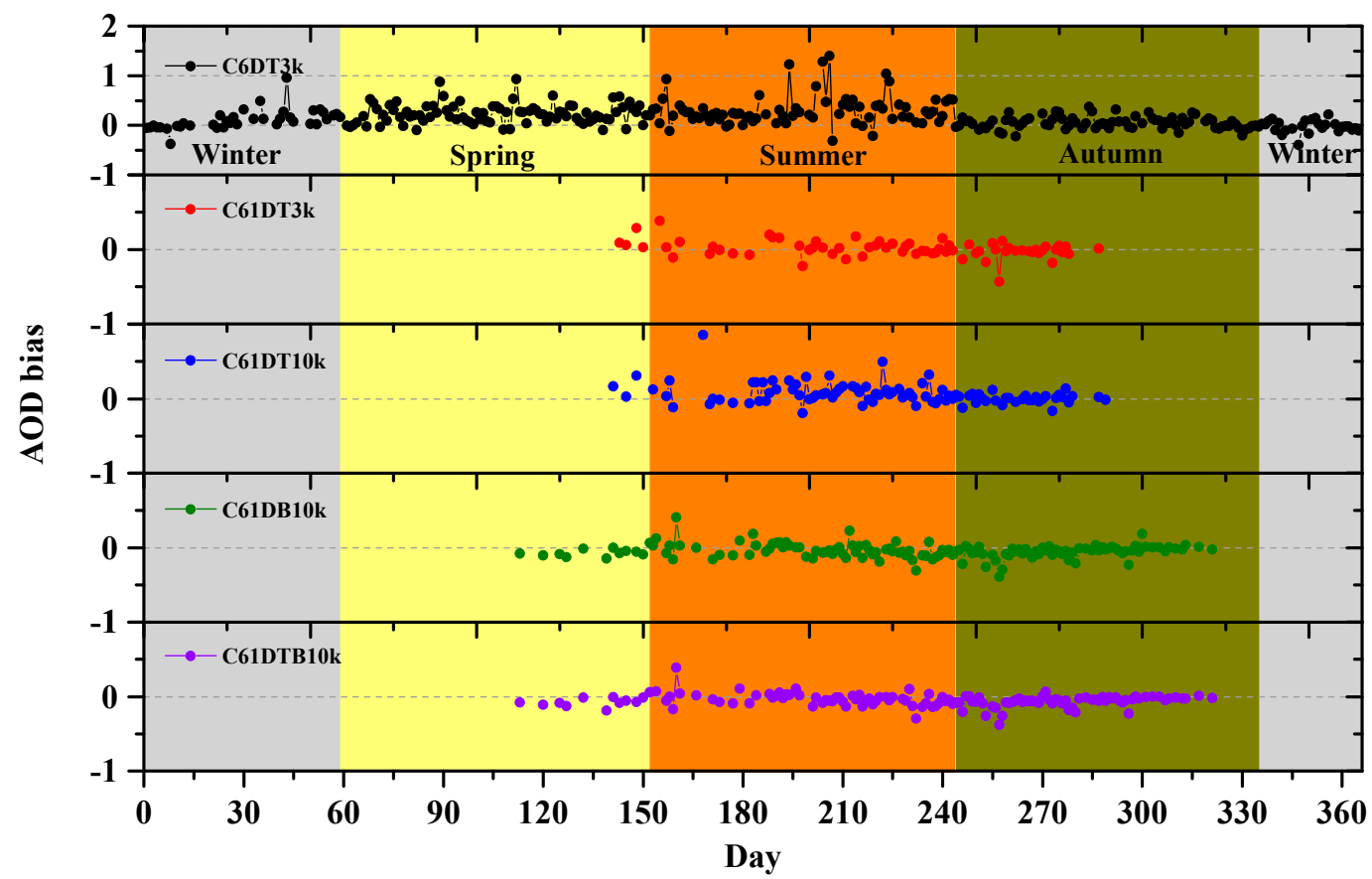

Figure 11. Seasonal variation of the Aqua-MODIS C6 and C6.1 AOD retrieval biases (QF $>0)$ of the CE318 AOD observations at $550 \mathrm{~nm}$ at the UL site. Note that the y-axis refers to the multi-year daily mean AOD bias values for the period of 1 July, 2002 to 31 December, 2014.

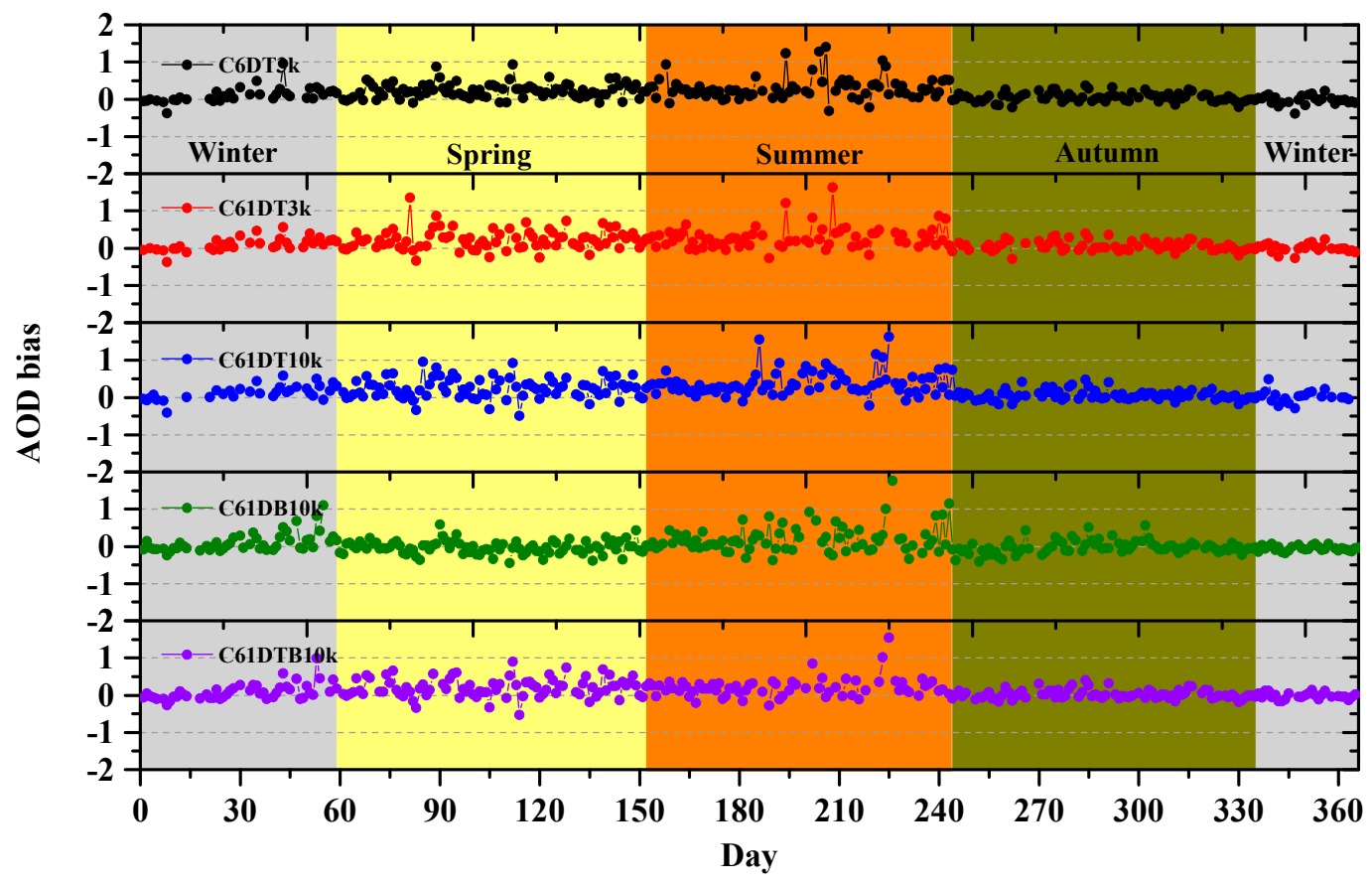

Figure 12. Seasonal variation of the Aqua-MODIS C6 and C6.1 AOD retrieval biases (QF $>0)$ of the CE318 AOD observations at $550 \mathrm{~nm}$ at the $\mathrm{ZZ}$ site. Note that the $\mathrm{y}$-axis refers to the multi-year daily mean AOD bias values for the period of 1 July, 2002 to 31 December, 2014.

\subsection{Spatial Distribution of High-Quality Aqua-MODIS AOD}

Figure 13 shows the spatial distribution of the five Aqua-MODIS C6 and C6.1 AOD products $(\mathrm{QF}=3)$ at $550 \mathrm{~nm}$ over the YERB. The blank areas represent areas without data. The reason might be due to the differences in the inversion algorithm of the different AOD products (mentioned in Section 2.1). The Aqua-MODIS DT 3K and DT10K C6 and C6.1 AOD retrievals in the northern YERB 
inland water system showed large areas of missing data, which indicated that not many high-quality DT AOD retrievals were available over these areas. On the other hand, DB and DTB C6.1 AOD retrievals were available over these areas. Moreover, the high-quality Aqua-MODIS retrievals showed good performance in the plateau and mountain areas in the upstream part of the YERB.
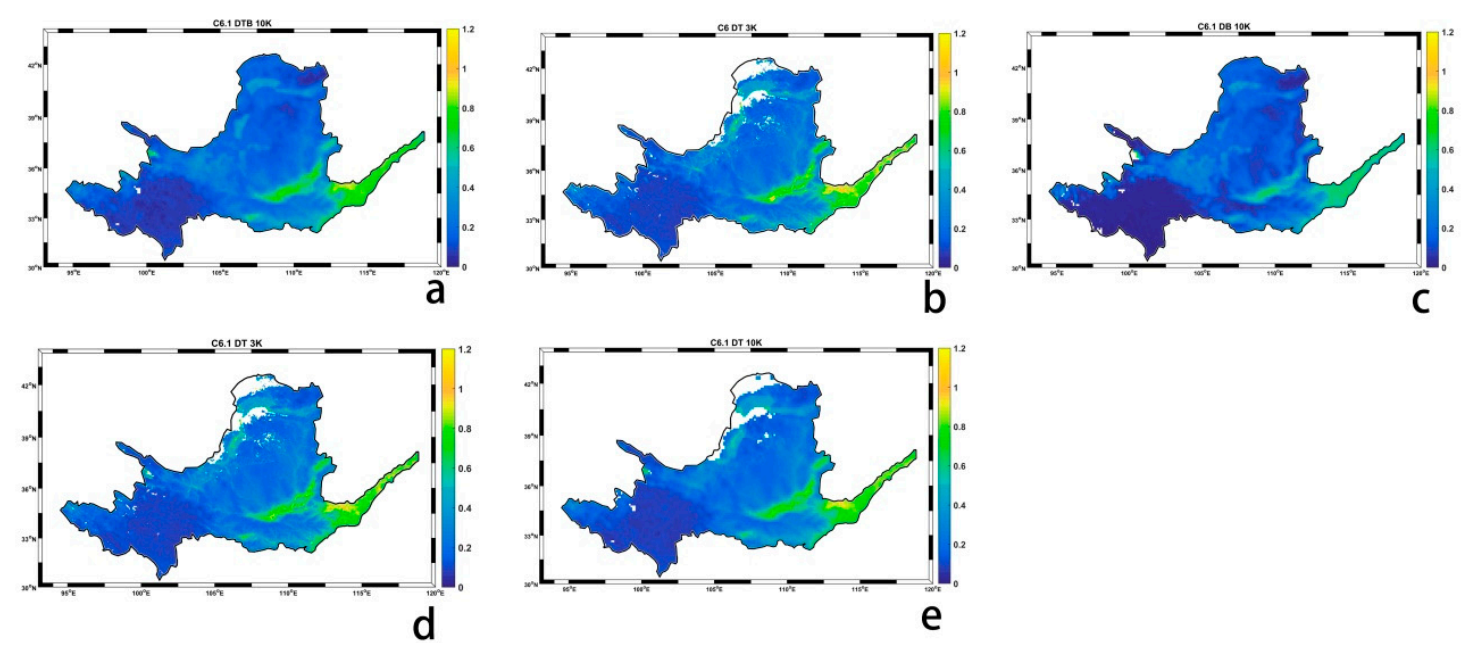

Figure 13. Spatial distribution of the annual high-quality Aqua-MODIS AOD at $550 \mathrm{~nm}$ : (a) C6.1 DTB10K AOD, (b) C6 DT3K AOD, (c) C6.1 DB10K AOD, (d) C6.1 DT3K AOD, and (e) C6.1 DT10K AOD retrievals $(\mathrm{QF}=3)$ over the YERB for the period of 1 July, 2002 to 31 December, 2014. The color scale refers to the AOD values.

As shown in Figure 13, the spatial distribution characteristics of the five Aqua-MODIS AOD products were nearly similar over the YERB. The high AOD values (AOD >0.8) mostly occurred in the eastern part of the YERB, including the North China plain, Shaanxi Province, and northern Henan Province, as these regions are relatively economically developed with large aerosol emissions, resulting in high aerosol loadings. At the same time, low AOD values (AOD < 0.4) mainly occurred in the upper reaches of the YERB, e.g., in the plateau and mountainous regions in the southwest of the YERB. These regions are relatively less economically developed with small aerosol emissions, resulting in low aerosol loadings. These results are consistent with a previous study in China [42].

In addition, the DT3K C6 (Figure 13b) and C6.1 (Figure 13d) AOD values were slightly higher compared to the other three products, especially in the lower reach of the YERB, where aerosol loadings were relatively large. This might be due to the remaining pixels, which were discarded by DT10K during the initial pre-processing and caused an overestimation in the DT3K [40]. In addition, the DB10K AOD retrievals were significantly underestimated compared to the DT10K and DTB10K AOD retrievals, which is consistent with the abovementioned results in Figure 5 and is supported by the findings of a previous study [49].

The relative mean bias values of MODIS-CE318 coincident retrievals at MW, LZ, UL, and ZZ stations are given in Table 8. Coincident observations of less than 200 were removed, as these could not reveal accurate results. Relative mean bias values can reflect the overestimation or underestimation of MODIS AOD, so the comparative results of every product at each station can be reflected clearly in Table 8 . Additionally, all MODIS products were almost underestimated at the LZ station. However, the DT and DTB products were overestimated at the ZZ station. Thus, the results of the DT were better (the RMB was almost 1) than DB and DTB products over the whole YERB. It can be concluded that, in the western semi-arid and arid regions of the YERB, the DT10K C6.1 was better, and in the north-central river regions and eastern plain regions of the YERB, the C6.1DB10K and C6.1DTB10K were better. 
Table 8. Relative mean bias (RMB) values of MODIS-CE318 coincident retrievals at $550 \mathrm{~nm}$ at MW, LZ, UL, and ZZ for the period of July 1, 2002 to December 31, 2014, where ALL represents all stations' data.

\begin{tabular}{cccccc}
\hline \multicolumn{5}{c}{ Aqua-MODIS Level 2 Aerosol Products (MYD04_L2/MYD04_3K) } \\
\hline Sites & DT3K C6 & DT3K C6.1 & DT10K C6.1 & DB10K C6.1 & DTB10K C6.1 \\
\hline MW & - & - & - & - & - \\
LZ & 0.61 & 0.62 & 0.67 & 0.45 & 0.46 \\
UL & - & - & - & - & - \\
ZZ & 1.22 & 1.22 & 1.27 & 0.96 & 1.16 \\
ALL & 1.01 & 1.00 & 0.94 & 0.71 & 0.82 \\
\hline
\end{tabular}

\section{Conclusions}

In this paper, Aqua-MODIS C6 and C6.1 DT and DB AOD products at $550 \mathrm{~nm}$ were evaluated against CE318 sunphotometer AOD measurements over the YERB from 1 July, 2002 to 31 December, 2014. This study concluded that:

(a) There are significant differences within the YERB concerning AOD.

(b) For some sites (e.g., LZ), significant deviations and annual-cycle differences exist between satellite and ground-based AOD.

(c) In general, (for the whole YERB), no single satellite AOD product performed satisfactorily. The scope of this paper is to demonstrate the present results and compare them with some recent AOD products.

(d) In the western semi-arid and arid land regions of the YERB, C6.1 DT10K performed better against the ground-based sunphotometer data, and the performances of C6.1 DB10K and DTB10K were satisfactory over the north-central water systems or river regions of the YERB and over the eastern plain regions of the YERB.

(e) The DT AOD retrievals were overestimated and underestimated for AOD $>1.1$ and AOD $<1.1$, respectively, over the YERB.

(f) The MODIS AOD retrievals had an $\mathrm{RMB}<0$ (underestimations) and showed certain seasonal variations (the absolute values of biases were lower in summer and higher in winter) across the LZ station, compared to the other stations.

(g) The C6.1 DB AOD retrievals were significantly underestimated over all the stations expect the ZZ station, where less underestimation was observed.

(h) Spatial distribution maps showed high AOD values (AOD > 0.8) over the eastern part of the YERB and low AOD values (AOD < 0.4) over the upper reaches of the YERB.

Author Contributions: M.Z. and W.L. conceived and designed the experiments; M.Z. performed the experiments; J.L. and B.Y. analyzed the data; B.Y. contributed analysis tools; M.Z. wrote the paper; F.Z., M.B., C.Z., and K.M.K. revised the manuscript.

Funding: This research was funded by the National Natural Science Foundation of China (41801282), Programs for Science and Technology Development of Henan Province (192102310008), the Key Scientific Research Project of Henan Institutions of Higher Learning (18B170007), the Nanyang Normal University Scientific Research Project (ZX2017014), the Science and Technology Project of Nanyang City (2017JCQY017), the Special Project of Jiangsu Distinguished Professor (1421061801003), and Deanship of Scientific Research, King Khalid University, Kingdom of Saudi Arabia (RGP2/54/40).

Acknowledgments: We also thank the NASA Langley Research Center for providing the experimental data. We would also like to thank the editors for modifying and revising this manuscript.

Conflicts of Interest: The authors declare no conflict of interest.

\section{References}

1. Edenhofer, O.; Seyboth, K. Intergovernmental Panel on Climate Change (IPCC). Encycl. Energy Nat. Resour. Environ. Econ. 2013, 26, 48-56. 
2. Zhang, M.; Ma, Y.; Wang, L.; Gong, W.; Hu, B.; Shi, Y. Spatial-temporal characteristics of aerosol loading over the Yangtze River Basin during 2001-2015. Int. J. Climatol. 2017, 38, 2138-2152. [CrossRef]

3. Wang, L.; Kisi, O.; Zounemat-Kermani, M.; Salazar, G.A.; Zhu, Z.; Wei, G. Solar radiation prediction using different techniques: Model evaluation and comparison. Renew. Sustain. Energy Rev. 2016, 61, 384-397. [CrossRef]

4. Ge, H.; Hao, X.; Wei, G.; Liu, J.; Du, J.; Xin, M.; Liang, A. Feasibility study on measuring atmospheric co2 in urban areas using spaceborne co2-ipda lidar. Remote Sens. 2018, 10, 985.

5. Ge, H.; Xin, M.; Ailin, L.; Tianhao, Z.; Yannan, Z.; Miao, Z.; Wei, G. Performance evaluation for China's planned $\mathrm{CO}_{2}$-IPDA. Remote Sens. 2017, 9, 768.

6. Lelieveld, J.; Evans, J.S.; Fnais, M.; Giannadaki, D.; Pozzer, A. The contribution of outdoor air pollution sources to premature mortality on a global scale. Nature 2015, 525, 367-371. [CrossRef] [PubMed]

7. Ge, H.; Wei, G.; Hong, L.; Xin, M.; Xiang, Z. Study on influences of atmospheric factors on vertical $\mathrm{CO}_{2}$ profile retrieving from ground-based DIAL at $1.6 \mu \mathrm{m}$. IEEE Trans. Geosci. Remote Sens. 2015, 53, 3221-3234.

8. Han, G.; Cui, X.; Liang, A.; Ma, X.; Zhang, T.; Gong, W. A $\mathrm{CO}_{2}$ profile retrieving method based on chebyshev fitting for ground-based dial. IEEE Trans. Geosci. Remote Sens. 2017, 55, 1-12. [CrossRef]

9. Guo, J.; Xia, F.; Zhang, Y.; Liu, H.; Li, J.; Lou, M.; He, J.; Yan, Y.; Wang, F.; Min, M.; et al. Impact of diurnal variability and meteorological factors on the $\mathrm{pm}_{2.5}$ - AOD relationship: Implications for $\mathrm{pm}_{2.5}$ remote sensing. Environ. Pollut. 2017, 221, 94-104. [CrossRef]

10. Ming, Z.; Wang, L.; Wei, G.; Ma, Y.; Liu, B. Aerosol optical properties and direct radiative effects over central china. Remote Sens. 2017, 9, 997.

11. Gong, W.; Zhang, M.; Han, G.; Ma, X.; Zhu, Z. An investigation of aerosol scattering and absorption properties in Wuhan, Central China. Atmosphere 2015, 6, 503-520. [CrossRef]

12. Zhang, M.; Ma, Y.; Gong, W.; Zhu, Z. Aerosol optical properties of a haze episode in Wuhan based on ground-based and satellite observations. Atmosphere 2014, 5, 699-719. [CrossRef]

13. Zhang, M.; Wang, L.; Bilal, M.; Gong, W.; Zhang, Z.; Guo, G. The characteristics of the aerosol optical depth within the lowest aerosol layer over the tibetan plateau from 2007 to 2014. Remote Sens. 2018, 10, 696. [CrossRef]

14. Qin, W.; Ying, L.; Wang, L.; Lin, A.; Xia, X.; Che, H.; Bilal, M.; Ming, Z. Characteristic and driving factors of aerosol optical depth over mainland China during 1980-2017. Remote Sens. 2018, 10, 1064. [CrossRef]

15. Kleidman, R.G.; O’Neill, N.T.; Remer, L.A.; Kaufman, Y.J.; Eck, T.F.; Tanré, D.; Dubovik, O.; Holben, B.N. Comparison of moderate resolution imaging spectroradiometer (modis) and aerosol robotic network (aeronet) remote-sensing retrievals of aerosol fine mode fraction over ocean. J. Geophys. Res. Atmos. 2005, 110. [CrossRef]

16. Che, H.; Xia, X.; Zhu, J.; Li, Z.; Dubovik, O.; Holben, B.; Goloub, P.; Chen, H.; Estelles, V.; Cuevasagulló, E. Column aerosol optical properties and aerosol radiative forcing during a serious haze-fog month over North China plain in 2013 based on ground-based sunphotometer measurements. Atmos. Chem. Phys. 2014, 14, 2125-2138. [CrossRef]

17. Che, H.; Zhang, X.; Xia, X.; Goloub, P.; Holben, B.; Zhao, H.; Wang, Y.; Zhang, X.; Wang, H.; Blarel, L. Ground-based aerosol climatology of China: Aerosol optical depths from the China aerosol remote sensing network (carsnet) 2002-2013. Atmos. Chem. Phys. 2015, 15, 7619-7652. [CrossRef]

18. Remer, L.A. The modis aerosol algorithm, products and validation. J. Atmos. Sci. 2005, 62, $947-973$. [CrossRef]

19. Chu, D.A.; Kaufman, Y.J.; Ichoku, C.; Remer, L.A.; Tanré, D.; Holben, B.N. Validation of modis aerosol optical depth retrieval over land. Geophys. Res. Lett. 2002, 29, 8007. [CrossRef]

20. Remer, L.A.; Tanré, D.; Kaufman, Y.J.; Ichoku, C.; Mattoo, S.; Levy, R.; Chu, D.A.; Holben, B.; Dubovik, O.; Smirnov, A.; et al. Validation of MODIS aerosol retrieval over ocean. Geophys. Res. Lett. 2002, 29, MOD3-1-MOD3-4. [CrossRef]

21. Levy, R.C.; Mattoo, S.; Munchak, L.A.; Remer, L.A. The collection 6 MODIS aerosol products over land and ocean. Atmos. Meas. Tech. 2013, 6, 2989-3034. [CrossRef]

22. Hsu, N.C.; Bettenhausen, C.; Sayer, A.M.; Hansell, R.; Seftor, C.S.; Huang, J. Enhanced deep blue aerosol retrieval algorithm: The second generation. J. Geophys. Res. Atmos. 2013, 118, 9296-9315. [CrossRef]

23. Remer, L.A.; Mattoo, S.; Levy, R.C.; Munchak, L. MODIS 3 km aerosol product: Algorithm and global perspective. Atmos. Meas. Tech. 2013, 6, 69-112. [CrossRef]

24. Sayer, A.M.; Hsu, N.C.; Bettenhausen, C.; Jeong, M.J. Validation and uncertainty estimates for MODIS Collection 6 “Deep Blue” aerosol data. J. Geophys. Res. Atmos. 2013, 118, 7864-7872. [CrossRef] 
25. Sayer, A.M.; Munchak, L.A.; Hsu, N.C.; Levy, R.C.; Bettenhausen, C.; Jeong, M.J. MODIS Collection 6 aerosol products: Comparison between aqua's e-deep blue, dark target, and "merged" data sets, and usage recommendations. J. Geophys. Res. Atmos. 2014, 119, 13965-13989. [CrossRef]

26. Bilal, M.; Nichol, J.E.; Wang, L. New customized methods for improvement of the MODIS C6 Dark Target and Deep Blue merged aerosol product. Remote Sens. Environ. 2017, 197, 115-124. [CrossRef]

27. Bilal, M.; Nichol, J.E. Evaluation of the NDVI-Based Pixel Selection Criteria of the MODIS C6 Dark Target and Deep Blue Combined Aerosol Product. IEEE J. Sel. Top. Appl. Earth Obs. Remote Sens. 2017, 10, 3448-3453. [CrossRef]

28. Bilal, M.; Nazeer, M.; Nichol, J.E. Validation of MODIS and VIIRS derived aerosol optical depth over complex coastal waters. Atmos. Res. 2017, 186, 43-50. [CrossRef]

29. Shen, X.; Bilal, M.; Qiu, Z.; Sun, D.; Want, S.; Zhu, W. Validation of MODIS C6 Dark Target Aerosol Products at $3 \mathrm{~km}$ and $10 \mathrm{~km}$ Spatial Resolutions Over the China Seas and the Eastern Indian Ocean. Remote Sens. 2018, 10, 573. [CrossRef]

30. Shen, X.; Bilal, M.; Qiu, Z.; Sun, D.; Wang, S.; Zhu, W. Long-term spatiotemporal variations of aerosol optical depth over Yellow and Bohai Sea. Environ. Sci. Pollut. Res. 2019, 26, 7969-7979. [CrossRef]

31. Bilal, M.; Qiu, Z.; Campbell, J.R.; Scott, S.; Shen, J.; Nazeer, M. A new modis c6 dark target and deep blue merged aerosol product on a $3 \mathrm{~km}$ spatial grid. Remote Sens. 2018, 10, 463. [CrossRef]

32. Patadia, F.; Gupta, P.; Christopher, S.A. First observational estimates of global clear sky shortwave aerosol direct radiative effect over land. Geophys. Res. Lett. 2008, 35, 228-236. [CrossRef]

33. Qin, K.; Zou, J.; Guo, J.; Lu, M.; Bilal, M.; Zhang, K.; Ma, F.; Zhang, Y. Estimating PM 1 concentrations from MODIS over Yangtze River Delta of China during 2014-2017. Atmos. Environ. 2018, 195, 149-158. [CrossRef]

34. Biswas, J.; Pathak, B.; Patadia, F.; Bhuyan, P.K.; Gogoi, M.M.; Babu, S.S. Satellite-retrieved direct radiative forcing of aerosols over North-East india and adjoining areas: Climatology and impact assessment. Int. J. Climatol. 2017, 37, 4756. [CrossRef]

35. Kharol, S.K.; Badarinath, K.V.S.; Sharma, A.R.; Kaskaoutis, D.G.; Kambezidis, H.D. Multiyear analysis of Terra/Aqua MODIS aerosol optical depth and ground observations over tropical urban region of Hyderabad, India. Atmos. Environ. 2011, 45, 1532-1542. [CrossRef]

36. Bilal, M.; Nichol, J.E.; Nazeer, M. Validation of Aqua-MODIS C051 and C006 operational aerosol products using aeronet measurements over pakistan. IEEE J. Sel. Top. Appl. Earth Obs. Remote Sens. 2016, 9, 2074-2080. [CrossRef]

37. Feng, N.; Christopher, S.A. Clear sky direct radiative effects of aerosols over Southeast Asia based on satellite observations and radiative transfer calculations. Remote Sens. Environ. 2014, 152, 333-344. [CrossRef]

38. Xiao, Q.; Zhang, H.; Choi, M.; Li, S.; Kondragunta, S.; Kim, J.; Holben, B.; Levy, R.C.; Liu, Y. Evaluation of VIIRS, GOCI, and MODIS Collection 6 AOD retrievals against ground sunphotometer observations over East Asia. Atmos. Chem. Phys. 2016, 16, 20709-20741. [CrossRef]

39. Nichol, J.; Bilal, M. Validation of MODIS $3 \mathrm{~km}$ resolution aerosol optical depth retrievals over Asia. Remote Sens. 2016, 8, 328. [CrossRef]

40. Kaskaoutis, D.; Kosmopoulos, P.; Kambezidis, H.; Nastos, P. Aerosol climatology and discrimination of different types over Athens, Greece, based on MODIS data. Atmos. Environ. 2007, 41, 7315-7329. [CrossRef]

41. Kosmopoulos, P.G.; Kaskaoutis, D.G.; Nastos, P.T.; Kambezidis, H.D. Seasonal variation of columnar aerosol optical properties over Athens, Greece, based on MODIS data. Remote Sens. Environ. 2008, 112, 2354-2366. [CrossRef]

42. Xia, X.; Che, H.; Zhu, J.; Chen, H.; Cong, Z.; Deng, X.; Fan, X.; Fu, Y.; Goloub, P.; Jiang, H.; et al. Ground-based remote sensing of aerosol climatology in China: Aerosol optical properties, direct radiative effect and its parameterization. Atmos. Environ. 2016, 124, 243-251. [CrossRef]

43. Bilal, M.; Nichol, J.E.; Chan, P.W. Validation and accuracy assessment of a Simplified Aerosol Retrieval Algorithm (SARA) over Beijing under low and high aerosol loadings and dust storms. Remote Sens. Environ. 2014, 153, 50-60. [CrossRef]

44. Bilal, M.; Nichol, J.E.; Bleiweiss, M.P.; Dubois, D.; Rse, J. A simplified high resolution MODIS Aerosol Retrieval Algorithm (SARA) for use over mixed surfaces. Remote Sens. Environ. 2013, 136, 135-145. [CrossRef]

45. Bilal, M.; Nazeer, M.; Nichol, J.; Qiu, Z.; Wang, L.; Bleiweiss, M.P.; Shen, X.; Campbell, J.R.; Lolli, S. Evaluation of Terra-MODIS C6 and C6.1 Aerosol Products against Beijing, Xianghe, and Xinglong Aeronet Sites in China during 2004-2014. Remote Sens. 2019, 11, 486. [CrossRef] 
46. Bilal, M.; Nichol, J.E. Evaluation of MODIS aerosol retrieval algorithms over the Beijing-Tianjin-Hebei region during low to very high pollution events. J. Geophys. Res. Atmos. 2015, 120, 7941-7957. [CrossRef]

47. Bilal, M.; Nichol, J.E.; Scott, N.S. A new approach for estimation of fine particulate concentrations using satellite aerosol optical depth and binning of meteorological variables. Aerosol Air Qual. Res. 2017, 17, 356-367. [CrossRef]

48. Chen, W.; Fan, A.; Yan, L. Performance of MODIS C6 aerosol product during frequent haze-fog events: A case study of Beijing. Remote Sens. 2017, 9, 496. [CrossRef]

49. He, L.; Wang, L.; Lin, A.; Zhang, M.; Bilal, M.; Wei, J. Performance of the NPP-VIIRS and Aqua-MODIS aerosol optical depth products over the Yangtze River Basin. Remote Sens. 2018, 10, 117. [CrossRef]

50. Muhammad, B.; Nazeer, M.; Qiu, Z.; Ding, X.; Wei, J. Global validation of modis c6 and c6.1 merged aerosol products over diverse vegetated surfaces. Remote Sens. 2018, 10, 475.

51. Wang, Y.; Chen, L.; Li, S.; Wang, X.; Yu, C.; Si, Y.; Zhang, Z. Interference of heavy aerosol loading on the VIIRS Aerosol Optical Depth (AOD) retrieval algorithm. Remote Sens. 2017, 9, 397. [CrossRef]

52. Wei, J.; Sun, L. Comparison and evaluation of different MODIS Aerosol Optical Depth products over the Beijing-Tianjin-Hebei region in China. IEEE J. Sel. Top. Appl. Earth Obs. Remote Sens. 2017, 10, 835-844. [CrossRef]

53. Zhang, M.; Ma, Y.; Gong, W.; Wang, L.; Xia, X.; Che, H.; Hu, B.; Liu, B. Aerosol radiative effect in UV, VIS, NIR, and SW spectra under haze and high-humidity urban conditions. Atmos. Environ. 2017, 166, 9-21. [CrossRef]

54. Wang, W.; Mao, F.; Pan, Z.; Du, L.; Gong, W. Validation of VIIRS AOD through a comparison with a sun photometer and MODIS aods over Wuhan. Remote Sens. 2017, 9, 403. [CrossRef]

55. Lijie, H.; Lunche, W.; Aiwen, L.; Ming, Z.; Xiangao, X.; Minghui, T.; Hao, Z. What drives changes in aerosol properties over the Yangtze River Basin in past four decades? Atmos. Environ. 2018, 190, 269-283.

56. He, L.; Wang, L.; Lin, A.; Ming, Z.; Bilal, M.; Tao, M. Aerosol optical properties and associated direct radiative forcing over the Yangtze River Basin during 2001-2015. Remote Sens. 2017, 9, 746. [CrossRef]

57. Wang, H.; Yang, Z.; Saito, Y.; Liu, J.P.; Sun, X.; Wang, Y. Stepwise decreases of the Huanghe (Yellow River) sediment load (1950-2005): Impacts of climate change and human activities. Glob. Planet. Chang. 2007, 57, 331-354. [CrossRef]

58. Georgoulias, A.K.; Alexandri, G.; Kourtidis, K.A.; Lelieveld, J.; Zanis, P.; Amiridis, V. Differences between the MODIS Collection 6 and 5.1 aerosol datasets over the greater mediterranean region. Atmos. Environ. 2016, 147, 310-319. [CrossRef]

59. Tao, M.; Wang, Z.; Tao, J.; Chen, L.; Wang, J.; Hou, C.; Wang, L.; Xu, X.; Zhu, H. How do Aerosol Properties Affect the Temporal Variation of MODIS AOD Bias in Eastern China? Remote Sens. 2017, 9, 800. [CrossRef]

60. Wang, L.; Gong, W.; Xia, X.; Zhu, J.; Li, J.; Zhu, Z. Long-term observations of aerosol optical properties at Wuhan, an urban site in Central China. Atmos. Environ. 2015, 101, 94-102. [CrossRef]

61. Schutgens, N.A.J.; Partridge, D.G.; Stier, P. The importance of temporal collocation for the evaluation of aerosol MODELS with observations. Atmos. Chem. Phys. 2015, 15, 26191-26230. [CrossRef]

62. Seo Park, S.; Takemura, T.; Kim, S.W. Comparison of aerosol optical depth between observation and simulation from MIROC-SPRINTARS: Effects of temporal inhomogeneous sampling. Atmos. Environ. 2018, 186, 56-73. [CrossRef]

63. Huang, J.; Zhang, W.; Zuo, J.; Jianrong, B.I.; Shi, J.; Wang, X.; Chang, Z.; Huang, Z.; Yang, S.; Zhang, S.; et al. An overview of the semi-arid climate and environment research observatory over the loess plateau. Adv. Atmos. Sci. 2008, 25, 906. [CrossRef]

(C) 2019 by the authors. Licensee MDPI, Basel, Switzerland. This article is an open access article distributed under the terms and conditions of the Creative Commons Attribution (CC BY) license (http://creativecommons.org/licenses/by/4.0/). 